\title{
A MULTIKULTURÁLIS NEVELÉS LÉTJOGOSULTSÁGA ÉS SZÜKSÉGESSÉGE AZ ÓBECSEI ÁLTALÁNOS ISKOLÁKBAN
}

Szerzők:

Horvát Leontina

Újvidéki Egyetem (Szabadka)

Kapás Mónika

Pécsi Tudományegyetem

Bagány Ágnes

Újvidéki Egyetem (Szabadka)

Első szerző e-mail címe:

hleni.0329@gmail.com
Lektorok:

Pintér Krekity Valéria

Újvidéki Egyetem (Szabadka)

Horák Rita

Újvidéki Egyetem (Szabadka)

Mező Ferenc

Eszterházy Károly Egyetem

Nemes Mgadolna

Debreceni Egyetem

Horvát, Leontina; Kapás, Mónika; Bagány, Ágnes (2017): A multikulturális nevelés létjogosultsága és szükségessége az óbecsei általános iskolákban Különleges Bánásmód, III. évf. 2017/2. szám, 7-28. DOI 10.18458/KB.2017.2.7

\begin{abstract}
Absztrakt
A munkánk célja bemutatni első sorban a multikulturalizmust, a multikulturális nevelés fontosságát és szükségességét - annak vajdasági megvalósulását - ugyanakkor kitérünk a kultúra fogalmi eredetére, összetettségére is, ugyanis kultúra nélkül a multikulturalizmus, s így a multikulturális nevelés gondolata sem fogalmazódhatott volna meg. Ma már mindannyian multikulturális környezetben élünk, ahol akarattal, vagy akaratunkon kívül nap, mint nap, különböző kultúrájú nemzetekkel érintkezünk, találkozunk, valamint együtt élünk. Pontosan ezért nagyon fontos az, hogy az emberek tisztába legyenek saját kultúrájuk fontosságával, ugyanakkor mások kulturális szokásaira is érzékenyek legyenek. Mutassanak hajlandóságot arra, hogy megismerjék, s elfogadják az övékénél akár sokkal eltérőbb szokásokkal, identitással, vallással rendelkező nemzetek szokásait, mert csak ilyen magatartással tudunk megteremteni egy békés világot.
\end{abstract}

Kulcsszavak: kultúra, multikulturalizmus, multikulturális nevelés, egymás elfogadása, különböző kultúrák találkozása

Diszciplína: pedagógia

\section{Abstract}

The main purpose of ours degree work is to present multiculturalism, the importance and necessity of multicultural rearing and the way it is realized in Vojvodina. We was also touch upon the conceptual origin and complexity of culture, because without culture there is no multiculturalism and the concept of multicultural rearing could have not been created either. Today we all live in a multicultural environment in which we are in touch, we meet or live together with nations of different cultures day by day, whether we want to or not. For this exact reason it is very important for people to become aware of the significance of their own 
culture and be sensitive to other cultural traditions in the same environment. They should express willingness to accept and get acquainted with other nations which might greatly differ in their tradition, habits, identity and religion. This is the only way we can create a peaceful world.

Keywords: culture, multiculturalism, multicultural education, accepting one another, meeting of different cultures

Discipline: pedagogy

\section{BEVEZETÖ}

Napjainkban a világ minden táján keverednek a különböző etnikai csoportok, s ezáltal másmás, sokszor szinte teljesen ellentétes kultúra találkozik egymással. A békés együttélés érdekében fontos az, hogy az emberek el tudják fogadni a mellettük élők kultúráját, szokásvilágát. Azonban ez sokszor csak elméletben valósul meg, s a gyakorlatban elmarad. Együtt élünk, viszont sokszor megpróbáljuk kikerülni a különböző nemzetiségekkel, kultúrákkal való érintkezést, ócsároljuk azok szokásait és ítéleteket mondunk egy egész nemzet, vagy akár kultúra felett, anélkül, hogy ismernénk azt. Többek között e probléma elhárítására megszületett egy eszme, a multikulturalizmus, amely azt hivatott elérni, hogy az emberek elfogadják egymást olyannak amilyenek, s ne ítéljenek el más embereket csak azért, mert azok nem ugyanazon vallást gyakorolják, más a börszínük vagy, mert más környezetböl érkeztek.

Sajnos azt kellett tapasztalnunk, hogy annak ellenére, hogy milyen nagy dolgot képvisel a multikulturalizmus, sokan nem találkoztak e szóval, s jelentésével, vagy ha mégis nem túl nagy figyelmet fordítottak ez iránt. Ezért munkánkban fontos pontnak tekintettük e szó értelmét, magyarázatát bemutatni. Továbbá dolgozatunk egy fontos pontja a multikulturális nevelés, róla való bővebb értekezés világviszonylatban, s szerbiai szinten is. Mivel egy olyan országban élünk (Szerbia) vajdasági magyarként, ahol mi is több nemzettel -szerbekkel, roma/cigányokkal stb. - élünk együtt, ahol látjuk, valamint tapasztaljuk a különböző kultúrák iránti ellenségességet, ezért különösen fontosnak tartjuk a multikulturalizmust és a multikulturális nevelést. $\mathrm{S}$, hol valósulhatna meg leginkább a multikulturális nevelés-a család mellett-, mint az iskolában? Fontosnak tartjuk azt, hogy a ma élö, dolgozó pedagógusok tisztában legyenek a multikulturális nevelés fontosságával, $\mathrm{s}$ különböző eszközök felhasználásával minden tölük telhetőt megtegyenek azért, hogy a kezeik közül kikerülö új nemzedék egy teljesen más világlátással lépjen ki a nagyvilágba, ahol minden nemzet, -akár kisebbségi, akár többségi kultúrát képvisel egy-egy ország területén -ugyanúgy elfogadja a tőle eltérő kultúra sajátosságait, mint ahogyan sajátját gyakorolja.

Az elhangzottak alapján született meg munkánk, mely, ahogyan azt már említettük, multikulturalizmus fogalmának boncolgatásáról, a multikulturális nevelésről, s azzal kapcsolatban elvégzett kutatás eredményeiről szól.

\section{A KULTÚRA FOGALMA, SOKSZÍNÜSÉGE}

Mielőtt a multikulturalizmusról, megjelenéséröl, a multikulturális nevelésről, annak szempontjairól szót ejtenénk, egy másik fontos fogalomról kell szólni, ez pedig nem más, mint a kultúra. Hiszen, ha nem lennének egymástól eltérő kultúrák -melyek mint pók a hálóját szövik össze a világot-, maga a multikulturalizmus, multikulturális nevelés is értelmét veszítené, sőt, véleményünk szerint nem túlozva azt is elmondhatjuk, ha nem léteznének 
különböző kultúrák nem is született volna meg a multikulturalizmus eszméje. De milyen jelentést is takar a szó: kultúra?

A kultúra szó a latin „agricultura” szóból származik, mely földművelést jelent, később ez önállósodott, $\mathrm{s}$ vált az emberi gondolkodás fogalmi rendszerének részévé (T. Molnár, 2016). A kultúra fogalmának az értelmező kéziszótár három jelentést tulajdonít. Az első jelentés szerint a kultúra az emberiség által létrehozott anyagi és szellemi értékek összessége, a müvelődésnek valamely területe, illetve valamely népnél, valamely korszakban való megnyilvánulása. A civilizációval szembeállítva pedig, amely a technikai fejlettséget jelenti, a szellemi javak és a müveltség tartozik ide. A második jelentésben a kultúra egy személy müvelt mivoltára vonatkozik. A harmadik jelentésben a kultúra valaminek a termesztését, illetve biológiai értelemben tenyészetet jelent (Korpics, 2011).

A társadalomtudományi megközelítések a kultúra fogalmát annak tág értelmében használják. Ebben az értelemben a kultúrához hozzátartoznak egy adott társadalom intézményei, értékei és tapasztalatai, amelyek a szimbólumokat, és a különböző megnyilatkozási formákat kialakították. A kultúra fogalma így magában foglalja a szimbólumok, értékek olyan halmazát, amely mely generációról generációra öröklődik. Az emberi kultúra csak közösségi létben létezhet: A másokkal való érintkezésben, kommunikációkban, visszacsatolásokban bontakoznak ki és maradnak fenn a kulturális jelenségek (Korpics, 2011).

Minden ember egy adott kulturális háttérben nő fel. Az életét, mindennapi tapasztalatait, viselkedését jelentős mértékben meghatározzák azok a körülmények, amelyeket a kultúra biztosít számára, neveltetése nagyban függ az öt körülvevő kultúra jellemzőitől. A hétköznapi életben nagyon ritkán tudatosul bennünk az, hogy mi mindent tanultunk meg a környezetünkböl, miközben a magatartásunkat, érzelmeinket, gondolkodásunkat igen nagymértékben befolyásolni tudja a minket ért környezeti hatások (Torgyik-Karlovitz, 2006).

Láthattuk, hogy a kultúra már csak fogalmát tekintve is, igen sokrétü. Ezen felül azonban a kultúra egy igen összetett jelenség. Bassis, Gelles, valamint Levine állítása szerint a kultúra nem egyetlen elem, épp ellenkezőleg, különböző elemekből épül fel, mint a hiedelmek, értékek, normák, szimbólumok, technológiák és nyelvek, s ez ugyancsak azt az állítást támasztja alá, hogy a kultúra összetett és sokszínü. Ha belegondolunk abba, hogy a világ minden egyes kultúrája ilyen sokrétü, s egyik-másik kultúra szinte csak érintőlegesen hasonlít egymáshoz, nem nehéz elképzelni azt, hogy ezen kultúrák nehezen tudnak egymás mellett megélni, ha nem nyitottak a mellettük élő kultúra iránt. Itt kerül központi kérdéssé az, hogy az egymástól ellentétes kultúrával bíró nemzetek, hogyan éljenek egymás mellett békében. Erre válaszként több gondolat, eszme is felmerült az évek során, mint a probléma megoldásának eszköze, köztük a multikulturalizmus is, amely véleményünk szerint a leginkább emberbarát megoldás, mely megszületett e probléma megoldásának kezelésére. De vajon mit jelent a multikulturalizmus? A következőkben erről szólnánk néhány szót.

\section{MULTIKULTURALIZMUS}

A multikulturalizmus fogalma 1970-es években indult el, színhelyéül pedig elsősorban Amerika, illetve Ausztrália szolgált, ugyanakkor Európában, Hollandia és Nagy-Britannia mellett a Német Szövetségi Köztársaságban kezdtek foglalkozni elsők között ezzel a témával, viszont utóbbinál interkulturális nevelés néven honosodott meg. A német ajkú európai embereken kívül a francia nyelvhasználatban is ugyanezen néven terjedt el. Ezzel szemben a magyar szakirodalomban mindkét kifejezés megtalálható és alkalmazott (Pásztor, 2012).

Mint azt, fent említettük a magyar szakirodalomban az interkulturalitáson kívül a multikulturalizmus meghatározás is megtalálható. A multikulturalizmus fogalmának azonban többféle megfogalmazása van, amelyek azzal az elgondolással egyet értenek, amely arra 
irányul, hogy a soketnikumú társadalmak kulturális sokféleségét el kell fogadni (Kasler, 2011). A számtalan értelmezés, megfogalmazás közül mi egyet emelnénk ki, mely véleményünk szerint összefoglalja azt, hogy mit takar a multikulturalizmus kifejezés.

A multikulturalizmus nem más, mint egy ideológia, mely támogatja a kulturális és nemzeti sokszínűséget, illetve igyekszik megőrizni azt, ugyanakkor a kisebbségi és a domináns kultúrák gyakran egyenlőtlen viszonyára helyezi a hangsúlyt (Adatbank, 2015).

\section{MULTIKULTURÁLIS NEVELÉS JELENTÉSE, LÉTJOGOSULTSÁGA ÉS SZÜKSÉGESSÉGE}

A multikulturális nevelés, mint olyan, a multikulturalizmusból kiinduló ideológia, mely mind gyakrabban ismételt fogalommá vált a hazai pedagógiában is. Magyarországon, illetve Szerbiában, ezáltal Vajdaságban is egyre élénkülö figyelem veszi körül a nemzeti és etnikai kisebbségek társadalmi problémáit, különösen oktatását és munkaerö-piaci helyzetét (Torgyik-Karlovitz; 2006). Ezért tartjuk fontosnak ezen téma bővebb kifejtését. Ahogyan a multikulturalizmusnak, úgy a multikulturális nevelésnek is több megfogalmazása született, ezen gondolatok közül, Banks és Banks (2001) megfogalmazását emelném ki, mely a következőképpen lássa a multikulturális nevelést:

„A multikulturális nevelés, a nevelés azon területeként definiálható, amelynek fő célja egyenlő nevelési-oktatási lehetőségek biztosítása a különböző rasszokhoz, nemekhez, etnikai és kulturális csoportokhoz, szociális osztályba tartozó diákok számára. Az egyik legfontosabb célja hozzásegíteni valamennyi diákot ahhoz a tudáshoz, olyan attitüdökhöz, viszonyulásokhoz és képességekhez, amelyek egy plurális, demokratikus társadalom hatékony müködéséhez szükségesek, a különböző csoportokból származó emberek közötti interakciók, a kommunikáció sikeres működése, és annak érdekében, hogy a társadalom és a morál a mindenki számára elönyös, közös jót szolgálja."

Mindezekből leszürhető, hogy a multikulturális nevelés egy nevelési terület, mely nagy figyelmet fordít a kulturális különbségekre, egymás elfogadására, s ennek oktatását, nevelését már kisgyermekkortól fontosnak tartja.

Sok nyugati országban, de a fejletlenebb közép-kelet-európai régiókban manapság ugyancsak az a cél, hogy a kisebbségi diákok sikeres társadalmi integrációja megtörténjen, illetve az, hogy a multikulturális nevelés megvalósuljon. Mindezek nem csupán üres szavak, hanem tettek is követik őket. Példának okáért, a különböző európai és tengeren túli országok számos programot dolgoztak ki a különböző etnikai csoportok széles körének érintésével, annak érdekében, hogy a tanulóikat felkészítsék az etnikailag sokszínü társadalomban való hatékony részvételre, remélve azt, hogy segítséget tudnak nyújtani a diákjaiknak abban, hogy elfogadják, megismerjék a különböző rasszok és kultúrák, a vallási és etnikai, nemzeti kisebbségek közötti békéhez, megértéshez, és nem utolsó sorban egymás kölcsönös elfogadásához szükséges tudnivalókat, elvi kérdéseket. A multikulturális nevelés alapját az emberi és állampolgári jogok jelentik, amelynek keretében a fejlett országok deklarálják az esélyegyenlőséget, az egyenlő oktatáshoz való jogot, a hátrányos megkülönböztetés tilalmát minden egyes állampolgárnak, így a bevándorló, és a kisebbségekhez tartozó gyerekek számára éppúgy, mint a középosztálybeli, többségi társadalomból származó tanulóknak is. A demokratikus alapon müködő országok kimondják, hogy a kisebbségeket is ugyanazon jogok illetik meg, mint a többség tagjait, kultúrájuk őrzése, átörökítése egyetemes emberi jog (Torgyik-Karlovitz, 2006).

Utóbbi megállapításhoz azonban hozzáfüzendő az is, hogy egy valóban demokratikus alapon müködő ország a kisebbségeket elfogadja, tiszteli, azonban nem emelheti minden jog, törvény fölé. Sajnos a ma élő európai ember, a manapság „népvándorlásként” emlegetet nagytömegü muszlim bevándorlását csupán feketén és fehéren látja. Aki „fehéren lát” a 
bevándorolt népet szeretettel fogadja, amely dicséretes, ugyanakkor sokszor törvény fölé is helyezi őket, s nem várja el azt, hogy a bevándorló ugyanolyan hozzáállással fogadja el a többségi kultúrát, mint ahogyan az európai elfogadja az ő más nemzetből származó kultúráját. A másik véglet szerint azonban, azok, akik pusztán „feketén látnak”, s gyülölik a bevándorlókat, ezáltal megvetve mindent, amely egy kicsit is eltérő a saját kultúrájuktól, mely lassan egy olyan hozzáálláshoz vezet, ami ellent megy mindennemü elfogadásnak, így a multikulturalizmusnak, a multikulturális nevelésnek is. Véleményünk szerint szükség lenne egy harmadik „szürke látáshoz” is, amely során a különböző etnikumot, kultúrát képviselö emberek elfogadják egymást, ugyanakkor egyiküket sem helyeznek a társadalmi törvények, jogok fölé, s az emberi jogokat emlegetve nem takaróznak akkor, mikor törvényen felül cselekednek. Többek között ezen álláspont miatt is a mai kor emberének, gyerekeinek fontos multikulturális nevelésben részesülnie, hogy megtanulják elfogadni egymást, $\mathrm{s}$ békét kötni a tőlük eltérő kultúrából származóval, azonban itt fontos azt is megemlíteni, hogy nem csak a többségi kultúrának kell megismernie, illetve elfogadnia a kisebbség kultúráját, hanem a kisebbségnek is a többség kultúráját.

Ezen apróbb kitérőt követően összefoglalva az eddigieket elmondható, hogy a multikulturális nevelés egy olyan ideológia, mely számos országban beszélgetés tárgyát képezi, s egyes nyugati társadalmakban némelyek szerint már unásig emlegetett téma, ugyanakkor hazánkban még igencsak újszerü fogalomnak tekinthető, sokan még csak most barátkoznak a kérdéssel.

\section{MULTIKULTURÁLIS NEVELÉS SZERBIÁBAN - A VAJDASÁGBAN}

Mint az már az eddigiekben is kiderült, fontosnak tartjuk e téma szerteágazó boncolgatását, ami valószínüleg annak tudható be, hogy mi is egy olyan társadalomban élünk, ahol egy kisebbségi kultúrát képviselünk, a vajdasági magyarokét. Így valószínüleg ennek hatására megpróbálunk nyitott szemmel járni és elfogadni, megismerni más kultúrák sajátosságait, többek között a többségi szerb, vagy a mellettünk szintén kisebbségben élő roma/cigány kultúrát is. Azonban Szerbiában, s így Vajdaságban is, annak ellenére, hogy több kultúra él egymás között, sajnos nem jellemző az országra, illetve a vajdasági régióra, hogy túl nagy hangsúlyt fektetne a témára, persze ez nem jelenti azt, hogy abszolút nincsenek ez irányú törekvések. (Ezen törekvések között megemlítendő a Vajdasági Autonóm Tartomány Kormányának A multikulturalizmus és tolerancia érvényesítése Vajdaságban címü projektje, melynek elsődleges célja a kulturális sokféleség ápolása és az etnikumközi tolerancia szellemének fejlesztése a vajdasági polgárok körében. A projekt kisebb nagyobb sikerekkel valósul meg 2005 óta) Senki sem vitathatja azt, hogy minden nemzet fontosnak tartja a saját kultúrájának ápolását. A közös kultúra az egymáshoz tartozás jelének is tekinthetö, az egyénnek a közösségvállalását fejezi ki. Pontosan emiatt nem megalapozott az emberek legyen az szerb, magyar, zsidó, vagy roma/cigány nemzetiségü - azon félelme, miszerint az iskolákban a multikultúra tanításával, illetve több kultúra és vallás megismertetésével a gyerekek eltávolodnak saját kultúrájuktól, és összezavarodnak a többféle rendszer megismerése után -pedig sokszor ez a szemlélet jellemző hazánkra-. Éppen ellenkezőleg reagálnak a diákok az idegen kultúrákra. Nyitottsággal fordulnak feléjük, és állandóan hasonlóságokat, különbségeket keresnek saját és mások kultúrájában, nyelvében. Sokaktól hallani azt a kijelentést, miszerint a többnyelvüség és több kultúrában való felnövés, vagy idegen kultúra elfogadása identitásproblémákat okoz, pedig ez egy téves hozzáállás. Elképzelhető, hogy egy magyar gyermek a megszokottnál eltérő például szerb, vagy roma/cigány szokásokkal találkozik és a neki tetszőt fel is veszi, gyakorolja, de egyértelmüen tudja, ezt már egy másik kultúrából hozta. Mindez azonban nem jelenti azt, hogy tovább ne ismerné a magyar szokásvilágot, ne tudná, milyen a magyar tánc, mik a tipikus magyar ételek, 
vagy hogyan üdvözli egymást két magyar jó barát (Czachesz Erzsébet, 1997). Ezért fontos, hogy biztassuk a szerbiai/vajdasági iskolák tanulóit arra, hogy megismerjék a körülöttük élö nemzetek, de más nemzetek kultúráját is. Ugyanakkor véleményünk szerint ez nem valósulhat meg anélkül, ha nincs a gyermek hátterében egy multikulturalizmust pozitívan szemlélő család. A család mellett azonban egy másik fontos pont egy olyan oktatási intézmény, ahol olyan pedagógus taníthatja, nevelheti, aki nyitott a kultúrák felé, illetve nem ismeretlen számára a multikulturális nevelés sem. A multikulturális nevelésnek nagy jelentősége van napjainkban, így a Vajdaságban élő pedagógusokat is ennek a nevelési módnak a gyakorlására kell biztatni, hiszen ha egy gyermek olyan családban, egy olyan oktatási intézmény mellett nevelődik, ahol az elfogadás nagy hangsúlyt kap, későbbiekben felnőve, gyerekeiknek továbbadva biztosíthatnak egy erös elfogadó társadalmat.

Következő fejezetben leírt kutatásunk ad bepillantást arra, hogy a Vajdaságban élö, pontosabban óbecsei pedagógusok hogyan tekintenek, s milyen mértékben valósítják meg a multikulturális nevelést.

\section{AZ ÓBECSEI ÁLTALÁNOS ISKOLÁK PEDAGÓGUSAINAK VÉLEMÉNYE A MULTIKULTURÁLIS NEVELÉSRŐL}

A kutatásunkban a kérdőíves kikérdezés módszerét, eszközként pedig a kérdőívet használtuk. Ezen kérdőíves kutatás során nyitott és zárt kérdések is felhasználásra jutottak. Ezen kutatási módszert előnyösnek tartottuk abból a szempontból, hogy ebben az esetben a kérdöív anonim, így a személyes kérdésekre nagyobb eséllyel kaptunk öszinte választ, amely alapján nagyobb a valószínüsége annak, hogy a következtetések, melyeket a kérdöív egy-egy kérdésére adott válaszok vizsgálata után meghozni tudtunk nagyobb realitást képviselnek, mint abban az esetben képviseltek volna, ha névvel ellátott kérdőív kerül kiosztásra.

A felmérést Óbecse öt iskolájában végeztük el, név szerint: Samu Mihály Általános Iskola, Petőfi Sándor Általános Iskola, Sever Đurkić Általános Iskola, Zdravko Gložanski Általános Iskola, illetve a Bratstvo Speciális Általános- és Középiskola. A kérdőíveket a tanítóknak illetve tanároknak osztottuk ki. Tehát vizsgálatban egyaránt részt vettek az iskolák tanítói és tanárai is, a kiosztott kérdőívek közül végül az öt iskolából mindösszesen 41 személy volt érdekelt, s töltötte ki a kérdöívet. Az elkövetkezökben ezek alapján mutatjuk be a Vajdaságban elhelyezkedő Óbecse pedagógusainak véleményét a multikulturális nevelésröl, s annak megvalósulásáról. Az öt iskolát egységként véve vizsgáltuk, így egy egységes képet kapva az óbecsei pedagógusok véleményéről a multikulturális nevelést illetően.

\section{A kutatás eredményei}

Az eredmények ismertetése során a kérdőívben szereplő kérdések sorrendje, illetve az alábbiakban feldolgozásra kerülő kérdések sorszáma nem egyezik, mivel a háttéradatokat kérdéseit összeolvasztva jegyezzük le, grafikusan nem elemezzük.

\section{Háttéradatok bemutatása}

Az első kérdés a válaszoló nemére vonatkozott. Az öt iskola adatait összesítve arra az eredményre jutottunk, hogy a kérdőívet nagyobb számban nők töltötték ki, szám szerint 38an, míg férfi mindösszesen csak három volt a kitöltők között, egy a Samu Mihály Általános Iskolából, egy a Sever Đurkić Általános Iskolából, egy pedig a Zdravko Gložanski Általános Iskolából.

A következő kérdés a kitöltők lakhelyét volt hivatott megállapítani. Az eredményekből az derült ki, hogy a kérdőívet kitöltő tanítók, illetve tanárok lakóhelye megosztott. A legtöbben az öt iskolából, szám szerint 27-en, Óbecsét jelölték meg lakhelyüknek, 8-an Péterrévét, 5pedig Bácsföldvárat, melyekről tudva levő, hogy Óbecse község területéhez tartoznak. 
Egyetlen személy nyilatkozta azt, hogy nem él Óbecse község területén, ezen személy Újvidéket jelölte meg lakhelyéül.

A háttéradatok következő kérdése a válaszoló anyanyelvére vonatkozott. A válaszokból az derült ki, hogy a kérdőívet kitöltők túlnyomó része magyar anyanyelvü, számbelileg ez 39 kitöltőt jelent, míg mindössze csak 2 szerb anyanyelvü volt a kitöltők között. Ez az eredmény számunkra nem meglepő, hiszen a kérdőív csak magyar nyelven került kiosztásra így nem váratlan, hogy annak kitöltői magyar anyanyelvüek.

Az utolsó háttéradatra vonatkozó kérdés a kitöltő korát volt hivatott megállapítani. A válaszok alapján, arra a megállapításra jutottunk, hogy a kérdőívet kitöltők életkora változó. A kitöltők között legnagyobb számban 40-50 év közötti pedagógusok voltak, szám szerint ez 20 pedagógust jelölt, míg legkevesebben a 30-40 éves korosztályból -szám szerint 5 személytöltötték ki multikulturális nevelésre irányuló kérdőívet. Ezen kívül a kitöltők között voltak 20-30 éves korosztályból is, ezek száma 8 volt, illetve ugyancsak 8-an voltak az 50 év feletti korosztályból.

\subsection{Oktatási tapasztalat a más kultúrájú gyermekek oktatásában}

A kérdőív azon kérdésére, mely az oktatási tapasztalatra vonatkozik a más kultúrájú gyermekek oktatása terén, a kitöltők nagy része az igent karikázta be, szám szerint 32-en, míg a nemet összesen 9-en (1.ábra). Az arány, számunkra nem meglepö, hiszen, ahogyan az már többször elhangzott Vajdaság egy olyan régió, ahol több kultúra találkozik egymással. Mivel elszalasztottuk azon kérdést feltenni, hogy a kérdőívet kitöltő pedagógusok milyen kultúrából származó tanulókat oktattak, így azt grafikonnal pontos számok alapján nem tudjuk felmérni, azonban a kérdőív néhány kérdésére adott válaszból kiderül, hogy többnyire a magyaron kívül, a szerbbel csak ritkán, míg többségben a roma/cigány kultúrából származókat volt alkalmuk a pedagógusoknak oktatni ezen intézményekben, ami nem is meglepő azt figyelembe véve, hogy magyar tagozatokat tanítanak. Megerősíteni ezt az állítást csak saját tapasztalatainkal tudjuk, viszont tényként nem állapíthatjuk meg.

1. ábra: Volt alkalma eddigi munkája során más kultúrából származó gyerekkel foglalkozni? Forrás: Szerző.

\section{Volt alkalma eddigi munkája során más \\ kultúrából származó gyerekkel foglalkozni?}

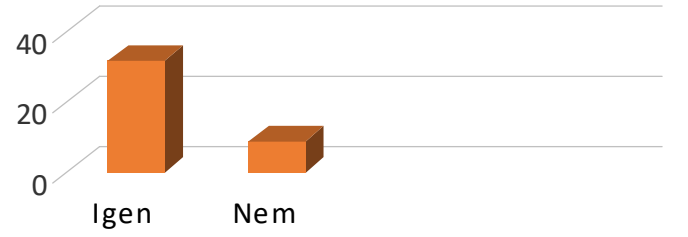

\subsection{Más kultúrából érkezö gyermekek száma}

Ahogyan a grafikonból (2. ábra) is látható, a válaszolók többsége, szám szerint 41-böl 12-en úgy nyilatkoztak, hogy nem tanítanak más kultúrából érkező tanulót. Az arányokat tekintve első pillantásra soknak tünhet, - hiszen többször is említésre került az, hogy Vajdaságban, így Óbecsén is több kultúra találkozik egymással-viszont, jobban megfigyelve láthatjuk azt, hogy 
igaz, hogy a kérdezők közül 12-en nem tanítanak más kultúrából érkezőt, ami nem mondható kis aránynak, ugyanakkor az is megfigyelhetö, hogy aki viszont tanít, az túlnyomó részt nagyszámú tanulót tanít. Kutatásunk (külön kérdésként a foglalkozásra nem tértünk ki, viszont a kérdőívek e szerint is elkülönítésre kerültek) szerint azok, akik nyilatkozatuk alapján nem, vagy kis számban tanítanak más kultúrájú gyerekeket, azok tanítók, míg, akik a nagy számokat képviselik a tanárok, hisz nekik alkalmuk van több osztályban tanítani, több más kultúrából érkezőt megismerni.

\section{2. ábra: Ön jelenleg hány más kultúrából érkező gyermeket tanít? Forrás:Szerző.}

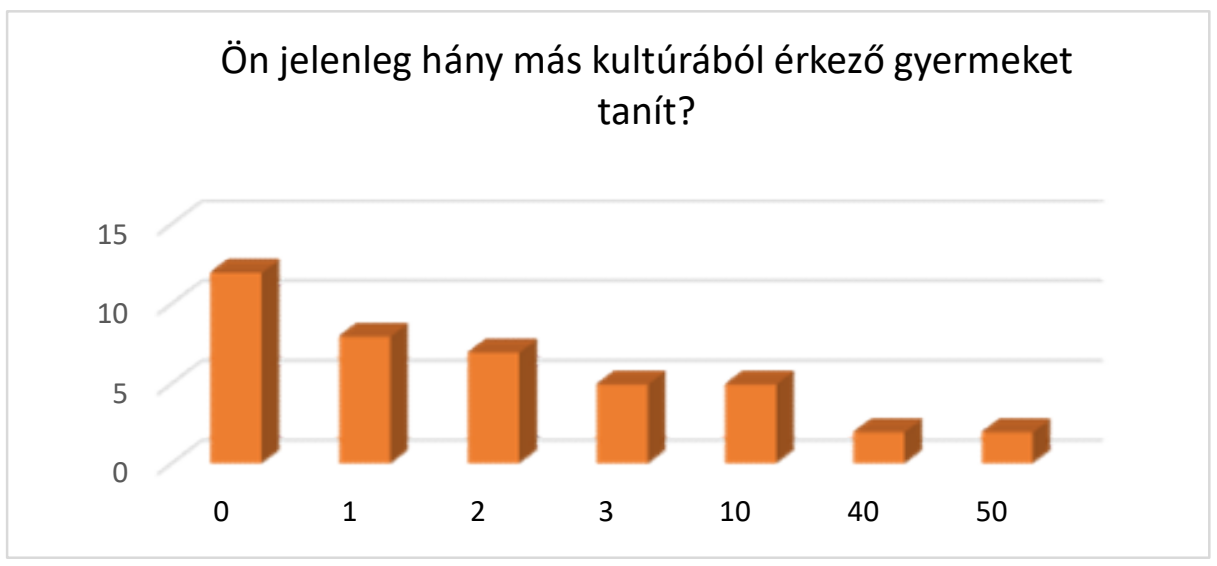

\section{Nyílt végü kérdések elemzésének bemutatása}

Az általános adatokat követően nyílt végü kérdéssel folytattuk kérdőívünket. Ezen típusú kérdések azt a célt szolgálták, hogy a pedagógusokat megerősítsük abban, miszerint az ő véleményükre, gondolatukra vagyunk kíváncsiak, a maguk megfogalmazásában. Másrészt pedig kíváncsiak voltunk arra, hogy a pedagógusok hogyan fogalmaznak, hogyan látják ök a problémát egy adott kérdéssel kapcsolatban.

Hogyan irná le röviden a multikulturális nevelés fogalmát és fontosságát?: A kérdést azzal a szándékkal fogalmaztuk meg, hogy megfigyeljük az óbecsei pedagógusoknak milyen elgondolásaik vannak a multikulturális nevelésről, s mennyit foglalkoztak annak fogalmi meghatározásával. A kérdöívet kitöltök közül e kérdést többen figyelmen kívül hagyták -8 személy. -, az okát csak találgatni lehet, mint például nem találta fontosnak, vagy nem alkotott véleményt a témával kapcsolatban. Azon pedagógusok, akik azonban választ adtak erre a kérdésre- szám szerint 33 kitöltő-, hasonló véleményt jegyzett le e kérdés alá. A következőket emelnénk ki a kapott válaszok közül:

- „A multikulturális nevelés elfogadást megértést jelent és fontosnak tartom.”

- „Kulturális és nemzeti sokszínűséget jelent.”

- „A multikulturális nevelés a különböző kultúrák értékeinek megismerése, elismerése és tiszteletben tartása, aminek az alapja a saját kultúránk ismerése és gyakorlása."

- „Megismerni más kultúrák alapvető jellegzetességeit, párhuzamot vonni a többségi kultúrával, rámutatni a közös és az eltérö értékekre."

- „A multikulturális nevelés lényege az, hogy az embereknek ne legyenek elöítéleteik egymással szemben."

- „A multikulturális nevelés fontos, mert a gyerekek meg kell, hogy tanulják elfogadni 
más emberek kultúráját, hogy toleránsak legyenek, ne tegyenek egymás között lényegi különbséget stb.”

- „Fontosnak tartom a multikulturális nevelést, mivel fontos, hogy a gyerekekkel megismertessünk más kultúrákat, a könnyebb alkalmazkodás, elfogadás miatt.”

- „A multikulturális nevelés fontos, hiszen fontos a különböző kultúrák kölcsönös elismerése, tisztelete, mindezt elsősorban a béke érdekében."

- „A multikulturális nevelés különösen fontos a vajdasági magyarok körében. Többnemzetiségü közösségben élünk, melyet, ha nem tudunk elfogadni, nem tudunk azonosulni vele, ha nem ismertetjük meg a tanulóval a fontosságát nem csak önnön identitástudata, de a közösségben betöltött helye, szerepe is sérülhet."

Ezen, illetve az említettekhez hasonló válaszok alapján elmondható, hogy többségében a pedagógusok, a multikulturális nevelés fontosságára mutattak rá, kiemelve Vajdaságban való fontosságát, ahol több nemzetiség él együtt. Egyetlen válaszoló volt csupán, aki arra mutatott rá, hogy véleménye szerint a multikulturális nevelés nem az iskolában, hanem a családban dől el, és az iskola, sem a tanító nem sokat tehet azért, hogy megvalósuljon a multikulturális nevelés. Érdekes és egyben kissé lehangoló is volt számunkra ezen válasz, hiszen egy részben igazat kell adni a válaszadónak. A családi háttér, a környezet valóban sokat befolyásolja a gyermek gondolkodását, abban viszont személy szerint nem tudunk egyet érteni, hogy az iskola keveset vagy szinte semmit sem tehet, hiszen a gyermek a legtöbb idejét a családján kívül az iskolában tölti, ahol legvalószínűbb, hogy találkozni fog más kultúrából származókkal. S mely hely lehetne a legalkalmasabb arra, hogy egymás elfogadására neveljék a gyermekeket, mint ott, ahol személyesen találkoznak egymással, illetve egymás szokásaival?

Soroljon fel néhány különbséget, melyek megnyilvánulnak a különbözö kultúrájú gyerekek között; osztályában, illetve az intézményben, ahol dolgozik!: E kérdésre ugyancsak 27 személy válaszolt, a fenn említett okok miatt. A kérdés nyílt típusú, s arra vár választ, hogy melyek azok a különbségek, melyek megnyilvánulnak a különböző kultúrájú gyerekek között. A kérdésre több hasonló jellegü válasz érkezett, legtöbbjük a nyelvi, vallási, viselkedésbeli különbségeket emelte ki. Íme néhány válasz, mely a kérdőív kitöltése során született:

- „más a nemzeti öntudatuk, más az iskolai munkához való hozzáállásuk”

- „más szokásaik vannak, más megvilágításban látják a világot, fegyelem nem ugyan olyan mértékü"

- „hitkultúrában keletkeznek a legnagyobb különbségek”

- „viselkedésbeli különbségek vannak, különbözik a tiszteletadás a felnőttek felé”

- „más a tanuláshoz való hozzáállásuk”

- „más a bőrszín, vannak nyelvi különbségek, vallási különbségek”

- „mások a higiéniás szokásaik, illetve a munkaszokásaik”

- „a kisebbségi kultúrákból érkezők általában visszafogottabban viselkednek”

- „más az ambíciójuk mértéke, sokszor a szövegértés is eltérő a különböző kultúrákból érkezőknél, más az anyagi hátterük"

- „az öltözködési szokások mások”

- „mások a konfliktuskezelések, egyes kisebbségi kultúrák agresszívabbak, más a nemzeti öntudatuk, kisebb az önbizalmuk a tanulás terén, viszont nagyobb hangúak a tananyagon kívüli véleménynyilvánítás során"

- „egyes kisebbségbe tartozók nem akarják betartani a szabályokat, elutasítanak minden nemü segítséget, nem fogadják el a többieket, kisebb csoportokat alkotnak az osztályon belül”" 
Mindezen kijelentésekből, valamint a sorok közé nézve arra a megállapításra juthatunk, hogy több pedagógus is a roma/cigány kultúrát képviselő kisebbségekre utalt, ami nem meglepő hisz a magyar tagozatokban legtöbbször előforduló más kultúra a roma/cigány. Ezen pedagógusok leginkább a higiéniát, az agresszivitást, a szegénységet, viselkedésbeli másságokat sorolták fel a különbségek közé. A válaszokból továbbá arra is bizonyítást kapunk, hogy még az ilyen kisebb városok közé tartozó várost is, mint Óbecse, több kultúra sző össze, valamint az óbecsei iskolák pedagógusai látják, s tisztában vannak a kultúrák közötti különbségekkel, így már csak a kérdés, hogy mennyit tesznek azért, hogy a kultúrák között harmonikus legyen a kapcsolat?

Véleménye szerint az intézményben ahol dolgozik, milyen mértékben valósul meg a multikulturális nevelés, oktatás?(3.ábra): E kérdésünket nyílt típusú kérdésnek szántuk, azonban végül a válaszokat négy csoportba be tudtuk kategorizálni, mégpedig a „kismértékben”, a „középszinten”, „nagymértékben” és a „más vélemény” alá. A 41 válaszoló közül 16-an úgy gondolják, hogy az intézményükben nem igazán fordítanak hangsúlyt a multikulturális nevelésre, 13-an úgy vélik, hogy az ő intézményükben nagymértékben megvalósul a multikulturális nevelés, mivel a pedagógusok mind hangsúlyt fektetnek arra, hogy a tanulóikkal megismertessék egymás kultúráját. Ezen kívül 10-en úgy vélik, hogy közepesen megvalósul a multikulturális nevelés, tehát az iskolájuk nem minden pedagógusa, de egy nagyobb részük figyelmet fordít erre a problémára. Mindössze két ezektől eltérő válaszadó volt, melyet a grafikonon a „más vélemény” alá kategorizáltunk. Ezen válaszolók egyike elvetette a multikulturális nevelést, mint megvalósítható dolgot, arra hivatkozva, hogy az intézményben, ahol dolgozik a gyerekek értelmi képességei miatt nehéz, szinte lehetetlen tudatosítani bennük ezt a látásmódot (szellemileg sérültek iskolájának pedagógusa adta az említett választ), a második személy viszont a következőt válaszolta: „Igyekszünk a gyerekeket arra nevelni, hogy elfogadják egymást, sőt véleményem szerint a szülöket is fontos egy-egy szülőértekezlet során erre nevelni, -nyilván más módon mint a gyerekeket-, azonban hiába van meg az igyekezet, sokszor kell szembesülni azzal, hogy a gyerekek érdektelenek a témával kapcsolatban, vagy pedig kinevetik a tölük eltérő kultúra szokásait.”

3. ábra: Az ön véleménye szerint az intézményben, ahol dolgozik milyen mértékben valósul meg a multikulturális nevelés, illetve oktatás? Forrás: Szerzö

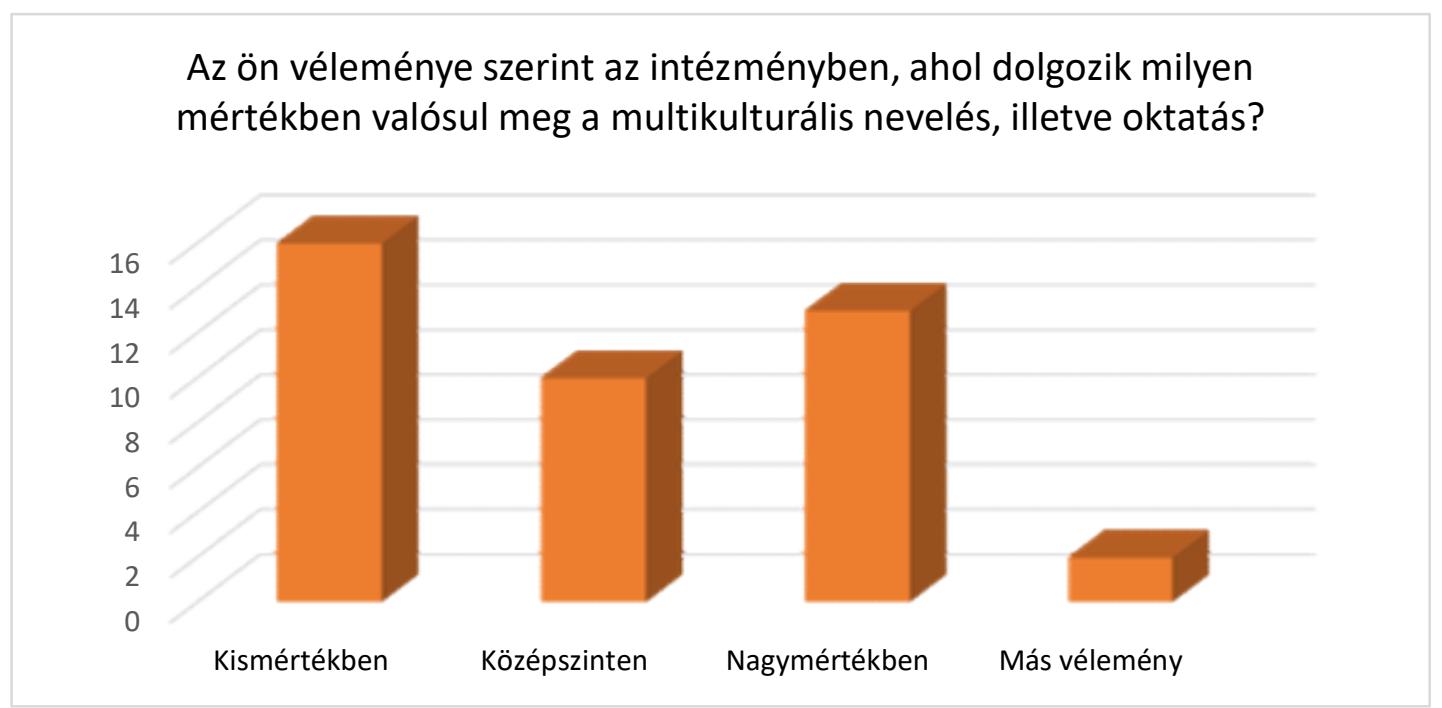


Milyen formában szövi bele az iskolai órák tartalmába a különbözö kultúrák sajátosságainak elfogadását? Soroljon fel néhány példát!: E kérdést a 41-böl mindösszesen 20-an válaszolták meg, a többi kitöltő nem válaszolt. A válaszolók közül ugyancsak hasonló feleltek születtek, melyeken-mint ahogyan az az előzőekben is említésre került - bizonyos mértékben megnyilvánul az, hogy az óbecsei iskolák magyar tagozataiban leggyakrabban kisebbségi kultúraként a roma/cigány kultúra jelenik meg. A válaszok közül kiemelnénk néhányat a következökben:

- „Osztályfönöki óra keretén belül beszélgetünk a különböző kultúrák szokásairól, hangsúlyt fektetve a magyar, szerb, illetve roma/cigány szokáskultúrára, illetve ha lehetőség adódik, filmeket vetítetek a témában."

- „Sok szó esik szünetekben, osztályfőnöki órák keretén belül, arról, hogy ne tegyenek különbséget egymás között, hogy attól, hogy más nemzetet képviselünk még mindannyian emberek vagyunk."

- „A különböző néphagyományokat néphagyomány tantárgy keretén belül beszéljük meg, beszélünk a különböző kultúrák szokásairól, valamint színházi élményeken keresztül próbálom beleszőni a különböző szokások elfogadását, megértését.”

- „Órák folyamán belevonom a tanítási egységekbe, ahol az kötődik hozzá, mint például: környezetünk, osztályfönöki, polgári, zene"

- „ETNO nap szervezése, közös kirándulások alkalmával szövöm bele a multikulturális nevelést."

- „Népi hangszerek, népdalok, népszokások ismertetésével nevelem tanulóimat más kultúrák elfogadására”

- „Drámajátékok feldolgozása során valósítom meg a multikulturális nevelést.”

- „Mivel több roma tanuló van az osztályban, a többiekkel megismertettem a „cigány zenét”, amit ma is szívesen énekelnek, hallgatnak; táncolnak rá; valamint a „roma konyha” ízvilágát is megismertettem tanulóimmal néphagyomány órán, bevonva a roma tanulót is -ő hozta a receptet és magyarázta el készítését."

Mindezen válaszokból az derül ki, hogy az óbecsei pedagógusok egy része megtesz minden tőle telhetőt annak érdekében, hogy tanulói megismerjék a velük együtt élő kultúrák szokásait.

\section{Zárt végü kérdések elemzése}

A zárt kérdések feldolgozása egy 5-ös fokozatú Likert-skála segítségével történt. A 10 tételes skála megbízhatóságának vizsgálatakor a Cronbach-alfa értéke 0,83 volt. A skála tehát megbízhatóan mér. A skála fokozatai: 1-egyáltalán nem, 2-néha egyet értek, 3-egyet is értek, meg nem is, 4-egyet értek, 5-teljes mértékben egyetértek.

A 10 tételes kérdőív faktoranalízise során kiderült, hogy az állítások három faktorba rendeződtek (1. táblázat). Az analízis eredményeként kapott Kaiser-Meyer-Olkin mutató értéke $0,68(p=0,001)$, ami még éppen elfogadhatóan magas értéket jelent, vagyis hangsúlyos a változók jelenléte a faktorok között. Minden vizsgált kérdés faktorsúlya 0,6 feletti, a megmagyarázott variancia $70,58 \%$.(1.táblázat). 
1.táblázat: Zárt végü kérdések faktoranalízise. Forrás: Szerzö.

\begin{tabular}{|c|c|c|}
\hline \multirow[b]{2}{*}{ Tételek } & \multicolumn{2}{|c|}{ Faktor } \\
\hline & 1 & 2 \\
\hline $\begin{array}{l}\text { Hazánkban, oktatási intézményeinkben a jelenleginél több figyelmet kellene fordítani a } \\
\text { kulturális kapcsolatokra. }\end{array}$ &, 830 & \\
\hline Amennyiben ön szerint vannak különbségek milyen mértékben nyilvánulnak meg ezek? & ,824 & \\
\hline Nyitott vagyok a multikulturális identitás fejlesztésére. & ,773 & \\
\hline A kisebbség kulturális szokásait tisztelni kell és erre nevelni tanulóinkat is. & ,724 & \\
\hline $\begin{array}{l}\text { A kulturális másság iránti toleranciát fontosnak tartom és növendékeimet is ez az elv szerint } \\
\text { nevelem. }\end{array}$ & ,719 & \\
\hline $\begin{array}{l}\text { Képes vagyok a problémát a kisebbségi kultúrához tartozók szemével látni és próbálom, } \\
\text { arra neveli diákjaimat, hogy ők is ezt tegyék. }\end{array}$ & ,654 & \\
\hline $\begin{array}{l}\text { Eddigi tapasztalatai alapján mennyire tartja sikeresnek a kisebbségi kultúrát képezö } \\
\text { gyerekek asszimilálódását a többségi kultúrába? }\end{array}$ & & ,920 \\
\hline $\begin{array}{l}\text { Eddigi tapasztalatai alapján hogyan ítéli meg, milyen mértékü a többségi kultúrájú } \\
\text { gyerekek alkalmazkodása a kisebbség kultúrájához? }\end{array}$ & & ,795 \\
\hline $\begin{array}{l}\text { Minden tőlem telhetővel küzdök a diszkrimináció minden formája ellen, beleértve a } \\
\text { rasszizmust is, és e nézet szerint nevelem növendékeimet is. }\end{array}$ & & \\
\hline $\begin{array}{l}\text { Ön mennyire érzi magát tapasztaltnak a nyelvi, vallási, etnikai és nemzetiségi mássággal } \\
\text { jellemezhetö tanulók nevelése terén? }\end{array}$ & & \\
\hline
\end{tabular}

\section{A többségi gyermekek alkalmazkodása}

A kérdöív azon kérdésére, mely a többségi gyermekek alkalmazkodását volt hivatott felmérni, a válaszolók egy 1-től 5-ig terjedő skálán jelölhették meg, hogy szerintük milyen mértékben alkalmazkodnak a többségi kultúrából származó gyerekek a kisebbség kultúrájához, ahol az 1-es szám az „egyáltalán nem alkalmazkodnak” kijelentést, míg az 5-ös a „teljes mértékben alkalmazkodnak” kijelentést takarta. A kérdöívet hárman nem töltötték ki. Az eredményekből az következtethető ki, hogy többségben az óbecsei pedagógusoknak (20 személy) úgy gondolja, hogy a többségi kultúrából származó gyerekek közepesen alkalmazkodnak a kisebbségi kultúrákhoz, illetve többnyire alkalmazkodnak viszont csak kis mértékben van olyan vélemény, mely szerint teljes mértékben alkalmazkodnának, és ami kellemes meglepetés, hogy senki sem gondolja úgy, hogy a tanulók, akikkel együtt dolgozik egyáltalán nem alkalmazkodik a kisebbség kultúrájához. Ebből következtethető az, hogy a kitöltő tanítók, tanárok szerint, az óbecsei általános iskolák diákjai nagyobb részt elfogadóak a más kultúrákból származóakkal és csak kisebb részük idegenkedik a tőle eltérő kultúrák elfogadásától.

A Spearman-féle rangkorrelációs együttható alapján a többségi kultúrájú és kisebbségi kultúrájú gyerekek alkalmazkodását megítélő vélemények, összefüggésben áll a következőkkel: különbségek közötti megnyilvánulások megítélését vizsgáló vélemények $(\mathrm{r}=0,40 \mathrm{p}=0,04)$. Ezen kívül az azt vizsgáló vélemények kérdéscsoportjával, miszerint a pedagógusok képesek a problémát a kisebbségi kultúrához tartozók szemével látni, szintén összefüggésben állnak egymással $(\mathrm{r}=0,44 \mathrm{p}=0,01)$. A pedagógusok fontosnak tartják a kulturális másság iránti toleranciát is és ez által nevelik növendéküket, összefüggésben állnak egymással $(\mathrm{r}=0,41 \mathrm{p}=0,01)$, továbbá a diszkrimináció minden formája elleni küzdelemre vonatkozó vélemények is összefüggésben állnak egymással $(\mathrm{r}=0,43 \mathrm{p}=0,01)$. 
4. ábra: Eddigi tapasztalatai alapján hogyan itéli meg, milyen mértékü a többségi kultúrájú gyerekek alkalmazkodása a kisebbség kultúrájához?. Forrás:Szerzö.

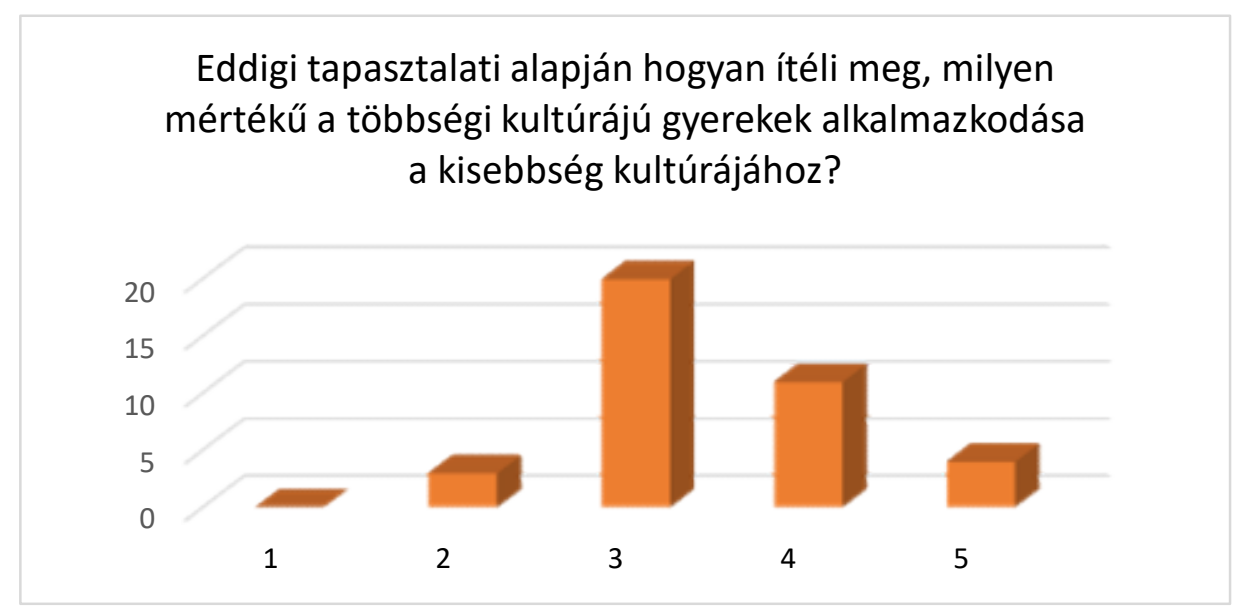

Kisebbségi gyermekek alkalmazkodása

Mivel mi nem abban látjuk a megoldást, hogy egy kultúra teljesen beolvadjon egy másik kultúrába, s saját kultúráját csak nyomelemekben, félve örizze, így nem tartjuk magunkat az asszimiláció hívőjének, azonban kíváncsiak voltunk az óbecsei pedagógusok véleményére is az ügyben. Ezen kérdés alatt a válaszolók többsége középszinten tartja sikeresnek, ha nem is teljesen sikeresnek a kisebbségi kultúrák asszimilálódását (5.ábra).

5. ábra: Eddigi tapasztalatai alapján mennyire tartja sikeresnek a kisebbségi kultúrát képezö gyerekek asszimilálódását a többségi kultúrába? Forrás: Szerző.

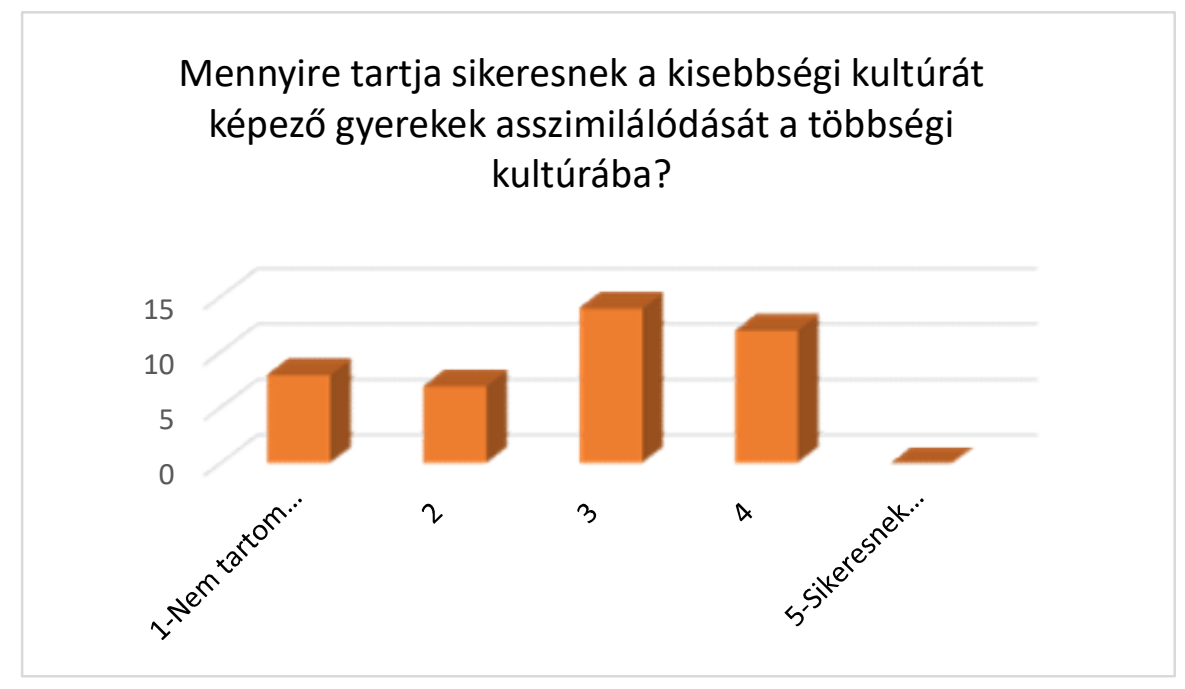




\section{Különbség a gyermekek között}

Ezen kérdés eredményeként a 41 válaszoló közül 27-en úgy nyilatkoztak,- tehát a többséghogy van különbség a kisebbségi és a többségi kultúrák között. Nekünk teljesen egyértelmü volt a „van” válasz, hiszen mégis más kultúráról van szó, valamilyen kulturális különbségek valószínüleg kell, hogy legyenek, ennek ellenére 14 kitöltő szerint nincs különbség a kisebbségi és többségi kultúra között abban az intézményben, ahol dolgozik. Ezen vélemények okát abban látjuk, hogy a különbségek az iskolai viselkedésük során nem vehetök észre, vagy pedig a pedagógusok csak a negatív különbségeket vették figyelembe, amely szerintük nincs, ez azonban pusztán feltételezés részünkröl.

6. ábra: Ön szerint az intézményben, ahol dolgozik, vannak-e különbségek a kisebbségi kultúrából származó, illetve a többségi kultúrából származó gyerekek között?. Forrás: Szerzö.

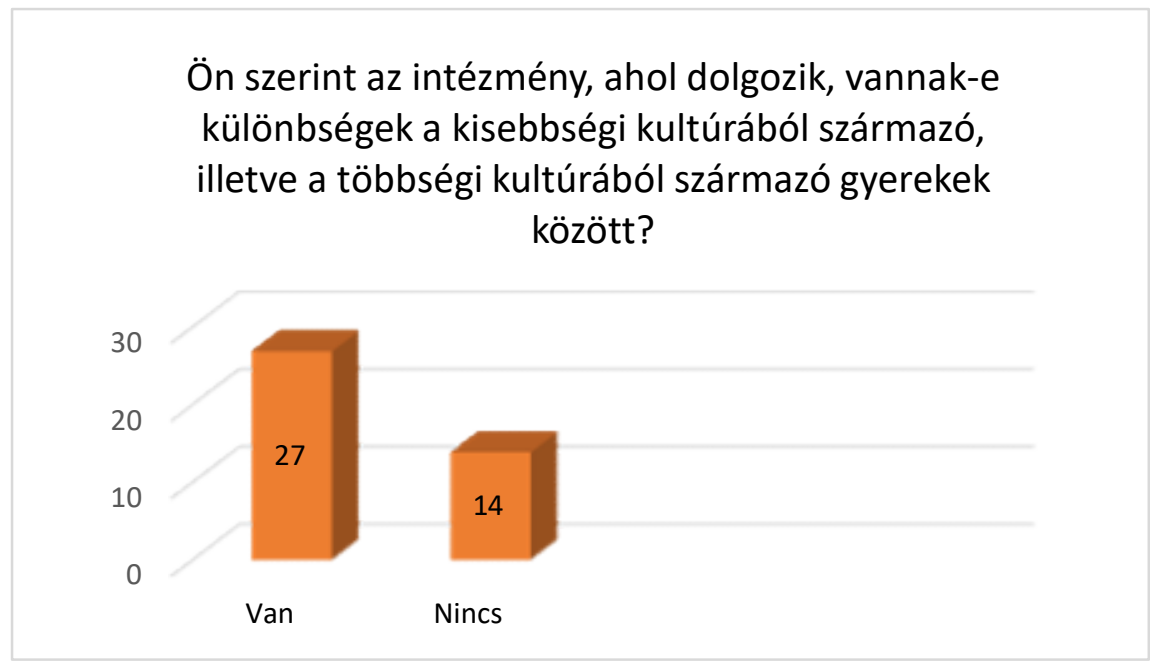

\section{A meglévö különbségek mértéke}

Mivel az előző kérdésben 14-en „nincs” választ karikázták be, így ebben a kérdésben ők nem voltak érdekeltek, így 27 válaszoló véleményét hasonlítottuk össze. A válaszolók közül 10-en úgy vélik, hogy bizonyos szinten megnyilvánulnak, 8-an úgy vélik, hogy nem túl nagymértékben, de azért vannak különbségek, 5-en gondolják azt, hogy csak kisebb mértékben nyilvánulnak meg, míg 4 válaszoló szerint kismértékben nyilvánulnak meg a különbségek. A skála 5-ös számát senki sem karikázta be, melyböl arra lehet következtetni, hogy túl nagymértékben nem nyilvánulnak meg ezekben az oktatási intézményekben különbségek a különböző kultúrájú gyerekek között.

A különbségek közötti megnyilvánulások megítélését vizsgáló vélemények, valamint a többségi kultúrájú és a kisebbségi kultúrájú gyerekek alkalmazkodását megítélő vélemények összefüggésben állnak egymással a Spearman-féle rangkorrelációs együttható alapján $(\mathrm{r}=0,40$ $\mathrm{p}=0,04)$. Összefüggésben állnak még a kisebbség kulturális szokásainak tiszteletben tartására irányuló véleményekkel is $(\mathrm{r}=0,56 \mathrm{p}=0,00)$. Az, hogy a pedagógusok képesek a problémát a kisebbségi kultúrához tartozók szemével látni összefüggésben állnak ezen véleményekkel $(\mathrm{r}=0,51 \mathrm{p}=0,01)$. Továbbá a korrelációs vizsgálatok alapján megállapíthatjuk, hogy a különbségek közötti megnyilvánulások megítélését vizsgáló vélemények, valamint az azt vizsgáló vélemények, miszerint a pedagógusok fontosnak tartják a kulturális másság iránti toleranciát együtt mozog $(\mathrm{r}=0,42 \mathrm{p}=0,03)$. Statisztikai szempontból szoros összefüggést mutat 
a különbségek megítélése valamint a multikulturális identitás fejlesztésére való nyitottság $(\mathrm{r}=0,60 \mathrm{p}=0,00)$, valamint az arra irányuló vélemények, miszerint hazánkban, oktatási intézményeinkben a jelenleginél több figyelmet kellene fordítani a kulturális kapcsolatokra szoros kapcsolatban állnak a különbségek megítésélésével $(\mathrm{r}=0,62 \mathrm{p}=0,00)$.

7. ábra: Amennyiben ön szerint vannak különbségek, milyen mértékben nyilvánulnak meg ezek? Forrás: Szerzö.

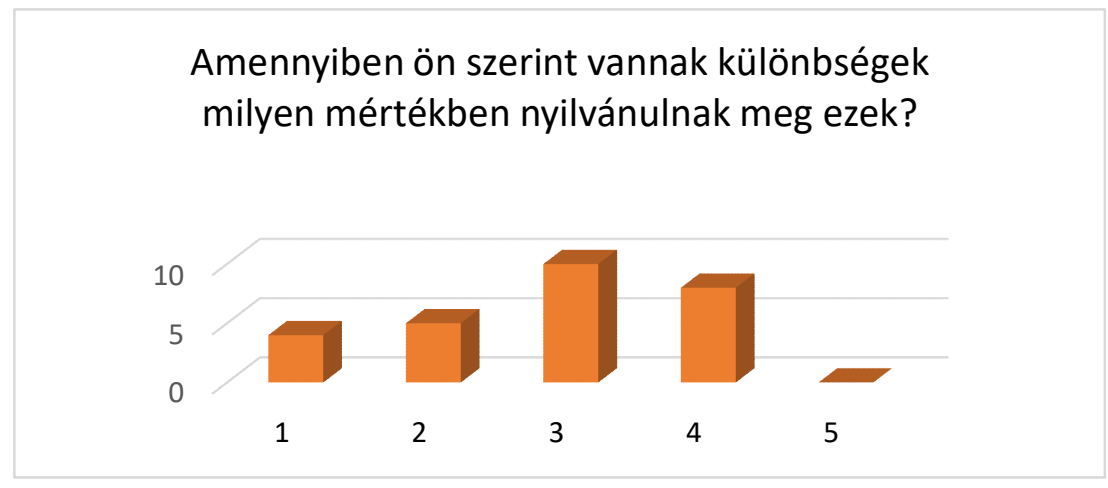

Nevelési tapasztalat a mássággal jellemezhető tanulóknál

A grafikonból (8. ábra) is kivehető, hogy a nagy többség úgy véli, hogy nagy illetve, komoly tapasztalattal rendelkezik a nyelvi, vallási, etnikai és nemzetiségi mássággal jellemezhető tanulók nevelése terén, míg a válaszolók közül 12 úgy, hogy középszintü tudással, tapasztalattal rendelkezik e téren, s csak elenyésző rész nyilatkozta azt magáról, hogy egyáltalán nincs tapasztalata. A válaszok aránya pozitív, hiszen eszerint az óbecsei iskolák tanítóinak, illetve tanárainak nagy része felkészült, illetve nagy tapasztalattal rendelkezik a multikulturális neveléssel kapcsolatban, remélhetőleg ez az arány az elkövetkezö években is hasonló marad, illetve javuló tendenciát fog mutatni.

8. ábra: Ön mennyire érzi magát tapasztaltnak a nyelvi, vallási, etnikai és nemzetiségi mássággal jellemezhetö tanulók nevelése terén?. Forrás: Szerzö.

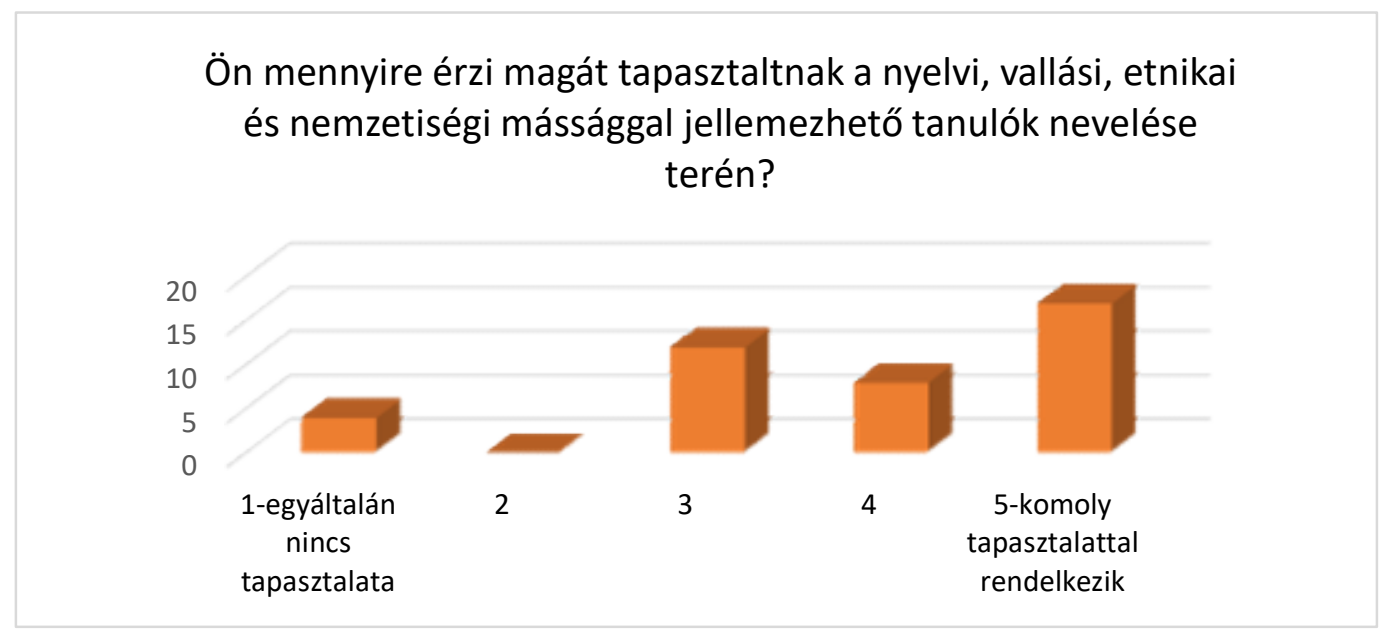


A Spearman-féle rangkorrelációs együttható alapján a nyelvi, vallási, etnikai és nemzetiségi mássággal jellemezhető tanulók nevelése során szerzett tapasztalatok mértékét vizsgáló vélemények szoros összefüggésben állnak a következőkkel: azt vizsgáló véleményekkel, miszerint a pedagógusok képesek a problémát a kisebbségi kultúrához tartozók szemével látni $(\mathrm{r}=0,38 \mathrm{p}=0,01)$, a diszkrimináció minden formája elleni küzdelemre vonatkozó véleményekkel $(\mathrm{r}=0,35 \mathrm{p}=0,03)$, illetve a multikulturális identitás fejlesztésére való nyitottságot megítélő véleményekkel $(\mathrm{r}=0,34 \mathrm{p}=0,03)$.

\section{A kisebbség kulturális szokásai}

A válaszolók legnagyobb része, - szám szerint 35 személy - teljes mértékben egyetértett azon állítással, hogy a kisebbség kulturális szokásait tisztelni kell és erre kell nevelni tanulóit is, míg 4-en egyet értettek, s a kérdőívet kitöltő pedagógusok közül mindössze ketten, vagyis csak egy elenyésző rész gondolta úgy, hogy részben egyet ért, részben pedig nem ért egyet ezen állítással. Számunkra ez az eredmény pozitív, ugyanis azt feltételezi, hogy az óbecsei általános iskolák pedagógusai fontosnak tartják a kultúrák megismerését, tiszteletét, $\mathrm{s}$ ez a látásmód szerint nevelik tanulóikat is, más szóval igyekeznek a multikulturális nevelést megvalósítani.

Statisztikai szempontból vagyis a Spearman-féle rangkorrelációs együttható alapján a kisebbség kulturális szokásainak tiszteletben tartására vonatkozó vélemények a következő kérdésekre adott válaszokkal állnak összefüggésben: a különbségek közötti megnyilvánulások megítélését vizsgáló véleményekkel $(\mathrm{r}=0,56 \mathrm{p}=0,00)$, az azt vizsgáló véleményekkel miszerint a pedagógusok képesek a problémát a kisebbségi kultúrához tartozók szemével látni $(\mathrm{r}=0,52$ $\mathrm{p}=0,00)$, az azt vizsgáló véleményekkel, miszerint a pedagógusok fontosnak tartják a kulturális másság iránti toleranciát $(\mathrm{r}=0,65 \mathrm{p}=0,00)$. Ezen felül továbbá ezen kérdés együtt mozog még a multikulturális identitás fejlesztésére való nyitottságot megítélő véleményekkel $(\mathrm{r}=0,65 \mathrm{p}=0,00)$, és azon véleményekkel, miszerint hazánkban, oktatási intézményeinkben a jelenleginél több figyelmet kellene fordítani a kulturális kapcsolatokra (Spearman-féle rangkorrelációs együttható alapján $\mathrm{r}=0,45 \mathrm{p}=0,00)$.

9. ábra: A kisebbség kulturális szokásait tisztelni kell és erre nevelni tanulóinkat is.Forrás: Szerzö.

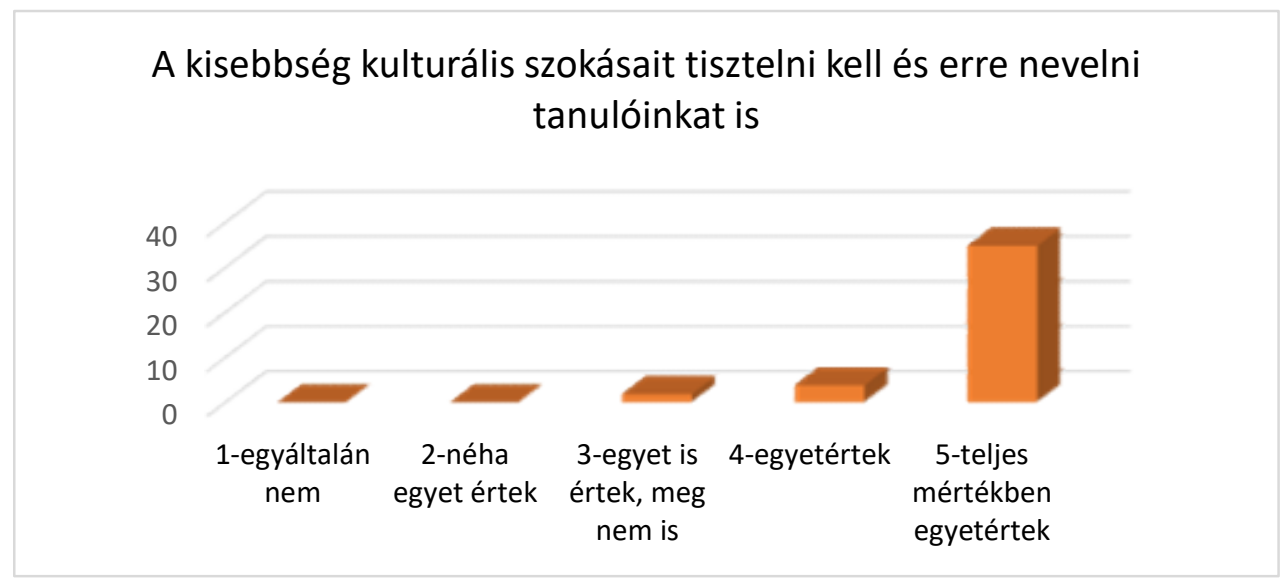




\section{Az oktatási problémák többoldalú vizsgálata}

Az eredmény hasonló az elözőhöz, ugyanis itt is a többség teljes mértékben egyetértett, -22 személy-, valamint 14 személy egyetértett azon állítással miszerint képes a problémát a kisebbségi kultúrához tartozók szemével látni, s erre neveli diákjait is. És ismét kevesen, szám szerint 5-en értettek egyet részben ezen állítással. A feltett állításra adott vélemény megegyezik azzal, melyre számítottunk, azon okból, amely már többször is felvetődött, hogy maguk a pedagógusok, akik kitöltötték túlnyomó részben vajdasági magyar kisebbséghez tartoznak, így átérzik a helyzetet, más kultúrák szemével is megpróbálják látni a felmerülő problémákat (10.ábra).

A Spearman-féle rangkorrelációs együttható alapján ezen kérdés a következő véleményekkel áll összefüggésben: a többségi kultúrájú és a kisebbségi kultúrájú gyerekek alkalmazkodását megítélő véleményekkel $(\mathrm{r}=0,44 \quad \mathrm{p}=0,01)$, a különbségek közötti megnyilvánulások megítélését vizsgáló véleményekkel $(\mathrm{r}=0,51 \mathrm{p}=0,01)$, a nyelvi, vallási, etnikai és nemzetiségi mássággal jellemezhető tanulók nevelése során szerzett tapasztalatok mértékét vizsgáló véleményekkel $(\mathrm{r}=0,38 \mathrm{p}=0,02)$, a kisebbség kulturális szokásainak tiszteletben tartására vonatkozó véleményekkel $(\mathrm{r}=0,52 \mathrm{p}=0,00)$, az azt vizsgáló véleményekkel, miszerint a pedagógusok fontosnak tartják a kulturális másság iránti toleranciát $(\mathrm{r}=0,74 \mathrm{p}=0,00)$, a diszkrimináció minden formája elleni küzdelemre vonatkozó véleményekkel $(\mathrm{r}=0,46 \mathrm{p}=0,01)$, a multikulturális identitás fejlesztésére való nyitottságot megítélő véleményekkel $(\mathrm{r}=0,72 \mathrm{p}=0,00)$.

A korrelációs vizsgálatok alapján megállapíthatjuk, hogy azon kérdéskör, hogy a pedagógusok képesek a problémát a kisebbségi kultúrához tartozók szemével látni, együtt jár azon véleményekkel, miszerint hazánkban, oktatási intézményeinkben a jelenleginél több figyelmet kellene fordítani a kulturális kapcsolatokra $(\mathrm{r}=0,61 \mathrm{p}=0,00)$.

10. ábra: Képes vagyok a problémát a kisebbségi kultúrához tartozók szemével látni és próbálom arra nevelni diákjaimat, hogy ők is ezt tegyék. Forrás: Szerzö.

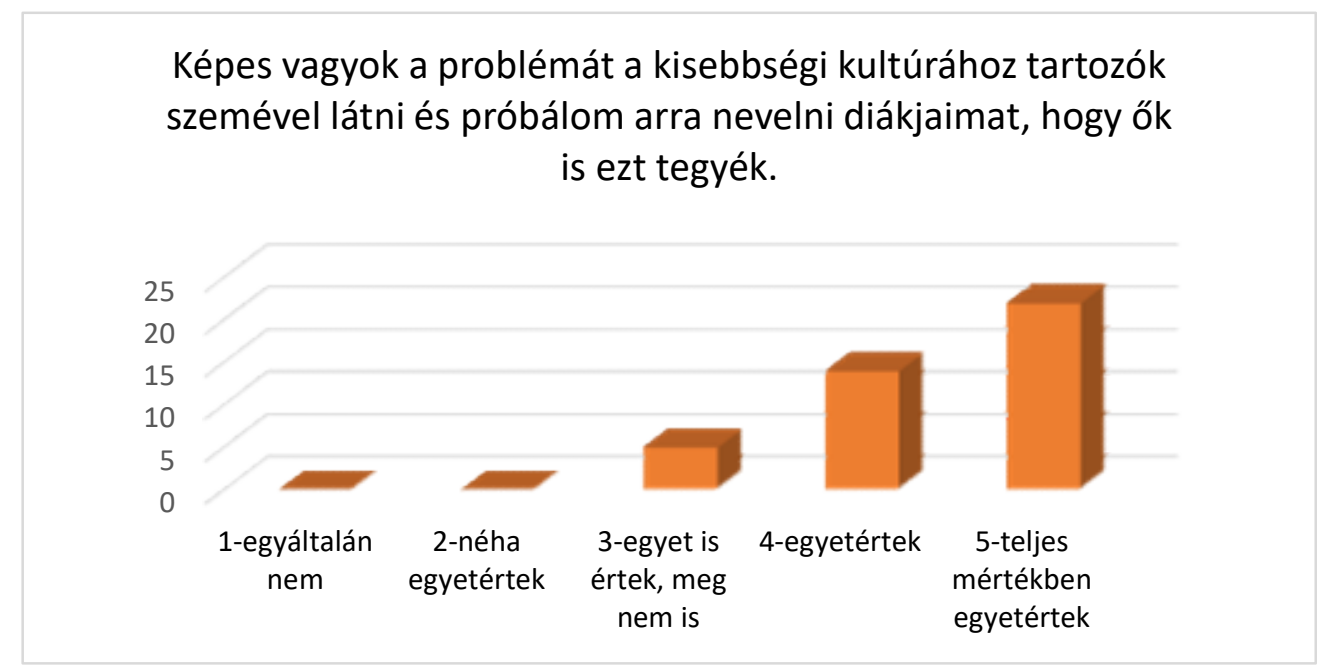

\section{A kulturális másság iránti tolerancia}

Azon állítás esetében, mely azt volt hivatott felmérni, hogy a pedagógusok milyen mértékben tartják fontosnak a kulturális másság iránti toleranciát, a többség ismételten 
egyetértett, szám szerint 28, viszont itt a pedagógusok véleménye megosztottabb volt. 9-en egyet értettek, 3-an részben értettek egyet, illetve 1 személy néha ért egyet, s csak kis mértékben tartja fontosnak azt, hogy a kulturális másság iránti tolerancia fontos lenne (11.ábra).

A Spearman-féle rangkorrelációs együttható alapján az azt vizsgáló vélemények, miszerint a pedagógusok fontosnak tartják a kulturális másság iránti toleranciát a következő kérdésekkel van összefüggésben: a többségi kultúrájú és a kisebbségi kultúrájú gyerekek alkalmazkodását megítélő véleményekkel $(\mathrm{r}=0,41 \mathrm{p}=0,01)$, a különbségek közötti megnyilvánulások megítélését vizsgáló véleményekkel $(0,42 \mathrm{p}=0,03)$, a kisebbség kulturális szokásainak tiszteletben tartására irányuló véleményekkel $(\mathrm{r}=0,65 \mathrm{p}=0,00)$, az arra vonatkozó véleményekkel, melyek szerint a pedagógusok képesek a problémát a kisebbségi kultúrához tartozók szemével látni $(\mathrm{r}=0,74 \mathrm{p}=0,00)$, a diszkrimináció minden formája elleni küzdelemre vonatkozó véleményekkel $(\mathrm{r}=0,51 \mathrm{p}=0,00)$, a multikulturális identitás fejlesztésére való nyitottságot megítélő véleményekkel $(\mathrm{r}=0,61 \mathrm{p}=0,00)$. A kulturális másság iránti tolerancia valamint azon vélemények melyek szerint az oktatási intézményeinkben a jelenleginél több figyelmet kellene fordítani a kulturális kapcsolatokra, összefüggésben állnak egymással (a Spearman-féle rangkorrelációs együttható $\mathrm{r}=0,32 \mathrm{p}=0,04$ ).

11. ábra: A kulturális másság iránti toleranciát fontosnak tartom és növendékeimet is ezen ez az elv szerint nevelem. Forrás:Szerzö.

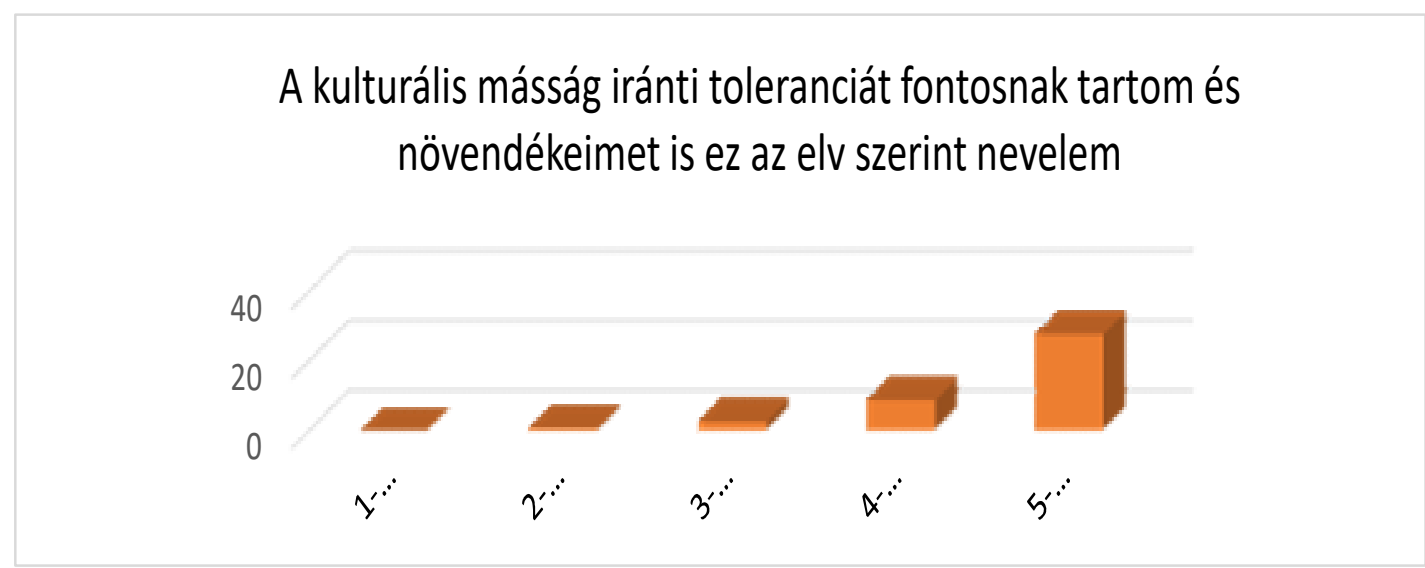

\section{A diszkrimináció elleni küzdelem}

A 41 kitöltő közül öten nem vették figyelembe az állítást, az eredmény a 36 válaszoló alapján született meg. Az eredmény ugyancsak pozitív, 29-en teljes mértékben egyetértettek, míg 6-an egyetértettek a fent említett állítással. Mivel a diszkrimináció ellen való küzdés fontos része a multikulturális nevelésnek, így jó azt megfigyelni, hogy az óbecsei pedagógusok nagy része küzd a diszkrimináció ellen, s diákjait is e nézet szerint neveli (12.ábra).

A diszkrimináció minden formája elleni küzdelemre vonatkozó vélemények, valamint a gyerekek alkalmazkodását megítélő vélemények összefüggésben állnak egymással a Spearman-féle rangkorrelációs együttható alapján $(\mathrm{r}=0,42 \mathrm{p}=0,01)$. Ezen kérdéskör még a következő kérdésekkel is korrelál: a nyelvi, vallási, etnikai és nemzetiségi mássággal jellemezhető tanulók nevelése során szerzett tapasztalatok mértékét vizsgáló véleményekkel 
$(\mathrm{r}=0,35 \mathrm{p}=0,04)$, az azt vizsgáló véleményekkel, miszerint a pedagógusok képesek a problémát a kisebbségi kultúrához tartozók szemével látni $(\mathrm{r}=0,46 \mathrm{p}=0,00)$, az azt vizsgáló véleményekkel, miszerint a pedagógusok fontosnak tartják a kulturális másság iránti toleranciát $(\mathrm{r}=0,51 \mathrm{p}=0,00)$ valamint a multikulturális identitás fejlesztésére való nyitottságot megítélö véleményekkel $(\mathrm{r}=0,52 \mathrm{p}=0,00)$.

12. ábra: Minden tölem telhetövel küzdök a diszkrimináció minden formája ellen, beleértve a rasszizmust is, és e nézet szerint nevelem növendékeimet is. Forrás: Szerzö.

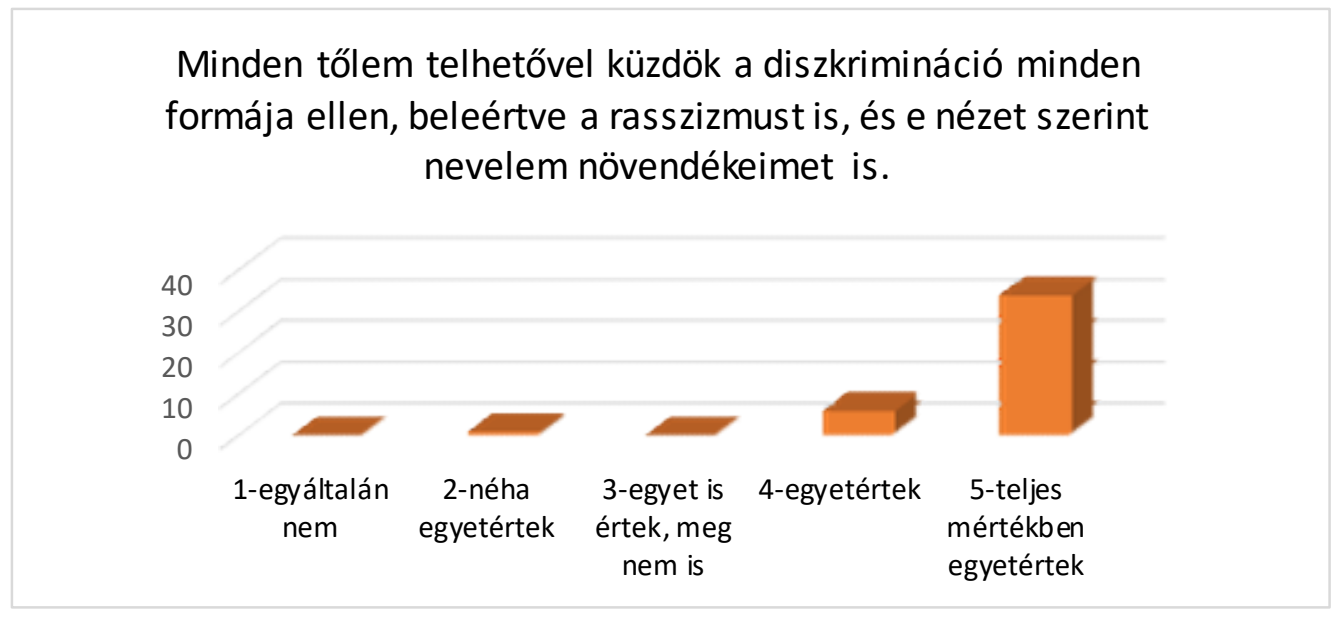

\section{A multikulturális identitás}

A válaszolók többsége ebben az esetben is egyetértett -11 személy-, illetve teljes mértékben egyetértett -26 személy- és a válaszolók kis része értett részben egyet -3 személy- illetve egy személy volt, aki néha ért egyet, azaz csak kis mértékben nyitott a multikulturális identitás fejlesztésére (13.ábra).

A multikulturális identitás fejlesztésére való nyitottságot megítélő kérdésre adott válaszok, valamint a különbségek közötti megnyilvánulások megítélését vizsgáló vélemények összefüggésben állnak egymással a Spearman-féle rangkorrelációs együttható alapján $(\mathrm{r}=0,31$ $\mathrm{p}=0,06)$ és a különbségek pedig megnyilvánulnak és összefüggést mutatnak $(\mathrm{r}=0,59 \mathrm{p}=0,00)$. Ezen kérdés összefüggést mutat még a nyelvi, vallási, etnikai és nemzetiségi mássággal jellemezhető tanulók nevelése során szerzett tapasztalatok mértékét vizsgáló véleményekkel $(\mathrm{r}=0,34 \mathrm{p}=0,03)$, a kisebbség kulturális szokásainak tiszteletben tartására irányuló véleményekkel $(\mathrm{r}=0,65 \mathrm{p}=0,00)$, az azt vizsgáló véleményekkel, miszerint a pedagógusok képesek a problémát a kisebbségi kultúrához tartozók szemével látni $(\mathrm{r}=0,72 \mathrm{p}=0,00)$, az azt vizsgáló véleményekkel, miszerint a pedagógusok fontosnak tartják a kulturális másság iránti toleranciát $(\mathrm{r}=0,61 \mathrm{p}=0,00)$, valamint a diszkrimináció minden formája elleni küzdelemre vonatkozó véleményekkel $(\mathrm{r}=0,52 \mathrm{p}=0,00)$. A multikulturális identitás fejlesztésére való nyitottság összefüggést mutat azzal a meglátással, hogy az oktatási intézményeinkben a jelenleginél több figyelmet kellene fordítani a kulturális kapcsolatokra (a Spearman-féle rangkorrelációs együttható alapján $\mathrm{r}=0,54 \mathrm{p}=0,00$ ). 
13. ábra: Nyitott vagyok a multikulturális identitás fejlesztésére.Forrás: Szerzö.

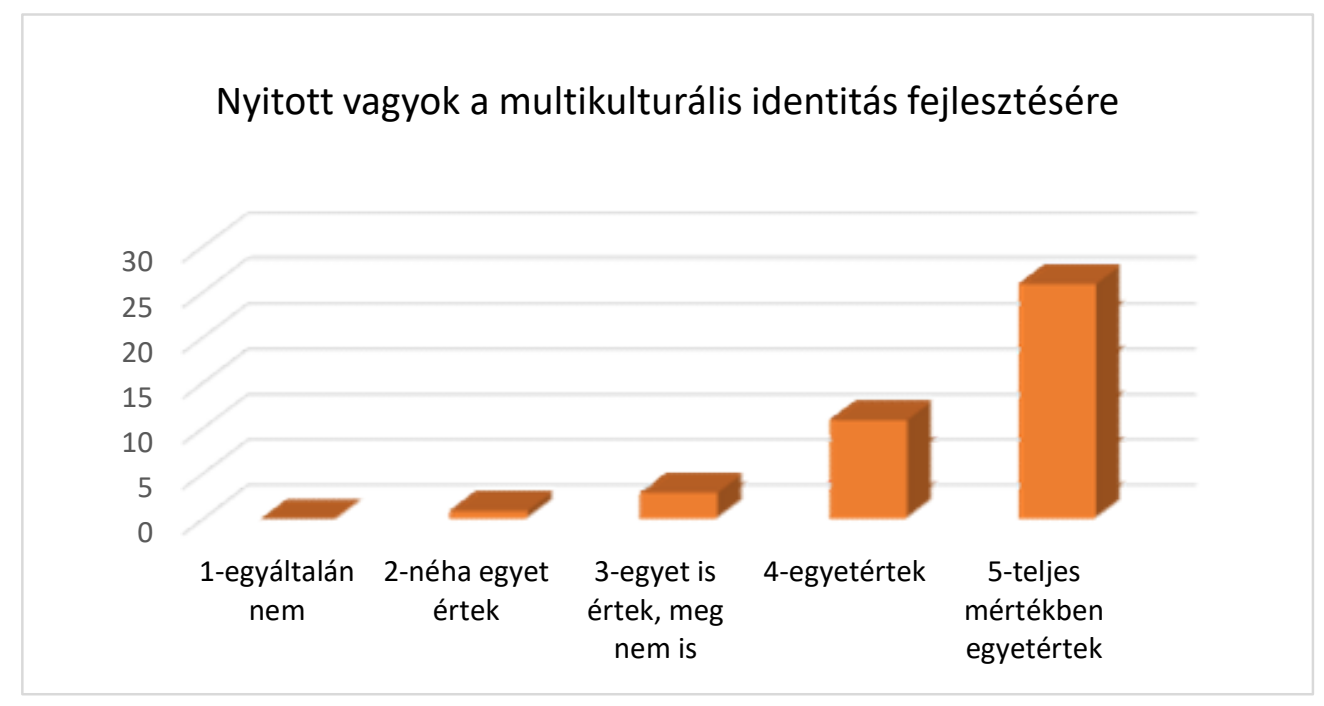

\section{Kulturális kapcsolatépités}

A 16. kérdés utolsó állítására adott válasz, az előző válaszok pozitív eredményei ellenére is, kissé elszomorító, hiszen az eredmény azt bizonyítja, hogy az oktatási intézményekben a jelenleginél több figyelmet kellene fordítani a kulturális kapcsolatokra, ami azt feltételezi, hogy jelenleg túl nagy figyelem nincs szentelve neki. Ugyanis a válaszolók közül 30-an, vagyis a túlnyomó többség teljes mértékben egyetért azzal, hogy a jelenleginél több figyelmet kellene fordítani a kulturális kapcsolatokra, míg 6-an egyetértenek, és mindössze 3 értenek egyet részben, és 2-en pedig néha, azaz kis mértékben azonosulnak az állítással.

14. ábra: Hazánkban, oktatási intézményeinkben a jelenleginél több figyelmet kellene forditani a kulturális kapcsolatokra.Forrás: Szerzö.

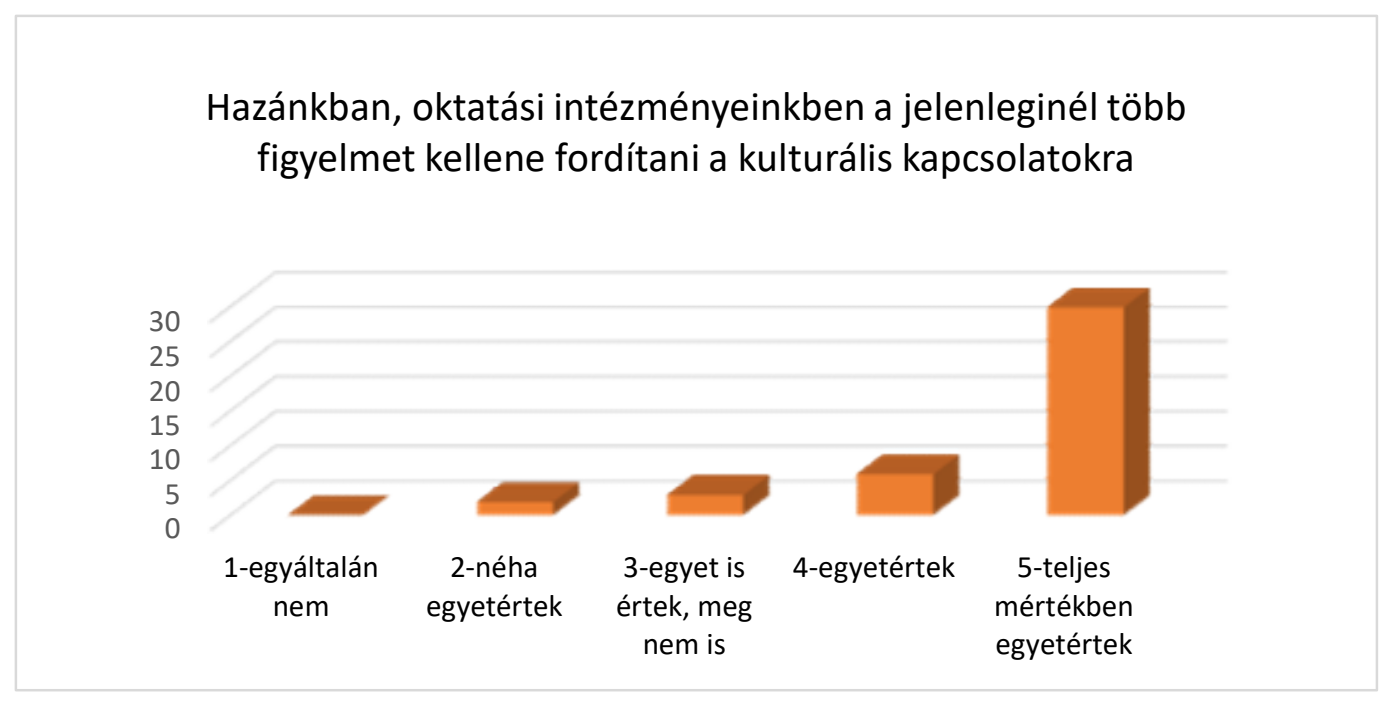

Az a kérdés, hogy hazánkban az oktatási intézményeinkben a jelenleginél több figyelmet kellene fordítani a kulturális kapcsolatokra statisztikai szempontból a következő kérdésekkel mutat összefüggést: különbségek közötti megnyilvánulások megítélését vizsgáló kérdéssel 
$(\mathrm{r}=0,62 \mathrm{p}=0,00)$, a kisebbség kulturális szokásainak tiszteletben tartására irányuló kérdéssel $(\mathrm{r}=0,45 \mathrm{p}=0,00)$. Ezen kívül azon állításokkal, hogy a pedagógusok képesek a problémát a kisebbségi kultúrához tartozók szemével látni $(\mathrm{r}=0,61 \mathrm{p}=0,00)$, azon állításokkal mely szerint a pedagógusok fontosnak tartják a kulturális másság iránti toleranciát $(\mathrm{r}=0,32 \mathrm{p}=0,04)$, a multikulturális identitás fejlesztésére való nyitottságot megítélő állításokkal $(\mathrm{r}=0,54 \mathrm{p}=0,00)$ (14.ábra).

Kutatásunk, néhol pozitív, néhol negatívabb irányú eredményekkel zárult. Mindenképpen kellemes meglepetés volt az, hogy az óbecsei pedagógusok- legalábbis válaszaik alapján-, megpróbálnak tenni a diszkrimináció ellen, tanulóikat különböző tantárgyakon belül, különböző módszerekkel próbálják meg átadni más kultúrák szokásvilágát, jellemzőit, $\mathrm{s}$ tőlük telhető legjobban próbálják tanulóikat az elfogadásra nevelni. Negatív vonulata a kutatásnak, azonban az, hogy válaszaikból kitünik, hogy az oktatási intézményben, ahol dolgoznak, a jelenleginél jóval több figyelmet kellene fordítani a multikulturális nevelésre. Véleményünk szerint azonban nagy lépés az, ha az intézményben dolgozó pedagógusok látják a problémát és próbálnak tenni is ellene, $\mathrm{s}$ a kutatás szerint a megkérdezett pedagógusok valamilyen módon, kisebb-nagyobb mértékben, de tesznek azért, hogy tanulóik kezeik közül úgy kerüljenek ki, hogy ismerik és elfogadják egymás különbözőségét.

\section{KONKLÚZIÓ}

Munkánkban fontosnak tartottuk a multikulturalizmus, illetve a multikulturális nevelés fontosságára, szükségességére felhívni a figyelmet -annak ellenére, hogy e szerteágazó témának csak egy bizonyos részét érintettük-, hiszen a világon egyre több országban napjainkban szinte egész Európában- jelent megoldásra váró problémát a különböző kultúrák, kisebbségek együttélése, annak kezelése. Egyre többen keresik a megoldást, egyesek az asszimilációban, némelyek az integrációban, s megint mások a multikulturalizmusban látják azt. A probléma azonban ma is fenn áll, ami azt jelenti, hogy egységes megoldás a mai napig nem született.

Tény az, hogy a mai társadalmakra a kulturális sokszínüség jellemző, s mindezek a kultúrák más értékeket, normákat képviselnek, más vallást tartanak magukénak stb. Ezért valószínűleg ott, ahol ilyen sok, egymástól teljesen különbözö kultúra él egymás mellett, elkerülhetetlenek különböző kisebb-nagyobb konfliktusok. Ugyanakkor, ha minden kultúrából származó egyaránt gyermekeit már kezdetektől arra próbálja nevelni, hogy elfogadóak legyenek a körülöttük élő kultúrák iránt, illetve, ha megismertetik velük a különböző kultúrák szokásait, nagy lépést tehetnek afelé, hogy a világ különbözö kultúrái elfogadóak legyenek egymással szemben, s ne ellenségként, hanem barátként üdvözöljék egymást, ha a világ bármely pontján találkoznak. Véleményünk szerint a multikulturális nevelés ezt hivatott elérni, pont ezért örülünk fent említett kutatásunk azon eredményének, mely szerint az óbecsei pedagógusok fontosnak tartják a multikulturális nevelést, ami igaz, hogy csak egy nagyon kis részét képviseli a világnak, de itt élnénk azon már-már elcsépelt mondással, miszerint kis lépés az embernek, viszont akár nagy lépés lehet az az emberiségnek. Továbbá fontos nem elfelejteni azt a bölcsességet sem, hogy az ellenségesség, ellenségességet, a gyülölet pedig gyülöletet szül, ezért reménykedünk abban, hogy az idő múlásával egyre kevesebbet hallhatunk majd a kultúrák közötti ellenségességekről és egyre többet azok békében éléséről.

\section{IRODALOM}

Banks, J. A. (ed.) - Banks, C. A. M. (ass. ed.) (2001). Handbook of research on multicultural education. Jossey-Bass, San Francisco. 
Banks, J. A. (2003). Multicultural Education. Goals and Dimensions. (Letöltés: 2016.08.12.). (Web: http.//depts.washington.edu/ceterme/view.htm).

Brandt, G. (1986). The realization of anti-racist teaching. The Palmer Press. London, New York and Philadelphia.

Czaches, E. (1997). Multikulturális nevelés (szócikk). In Báthory Zoltál-Falusi Iván (főszerk.) (1997). Pedagógiai lexikon. II. kötet. Budapest. Keraban Könyvkiadó.

Delors, J. (1997). Oktatás rejtett kincsei. A Jacques Delors vezette Nemzetközi Bizottság jelentése az UNESCO-nak az oktatás XXI. századra vonatkozó kérdéseiről. Budapest. Osiris Kiadó.

Feischmidt, M. (1997). Multikulturalizmus. Budapest. Osiris Kiadó.

Forray R., K. A multikulturális-interkulturális nevelés újabb értelmezései. (Letöltés: 2016.07.28.).

(Web:

https.//docs.google.com/viewer?a=v\&pid=sites\&srcid=ZGVmYXVsdGRvbWFpbnxjaWdv a3R8Z3g6MjI4NzQ2ZGJlMmVkOWQ0Mg).

Ivanović, J. (2014). Pedagógiai kutatás módszertanába - előadási jegyzet. Szabadka. Újvidéki Egyetem Magyar Tannyelvü Tanítóképző Kar.

Korpics, M. (2011). Az interkulturális kommunikáció. (Letöltés: 2016.08.08.). (Web: http.//www.janus.ttk.pte.hu/tamop/tananyagok/interkult_komm/2_a_kultura_fogalma_mod ellek_s_elmeletek_a_kultrrl.html).

Mészáros, M. (2004). Nemzeti sokszínüség, multietnicitás, multikulturalitás. egy biztonságosabb Európa felé. Budapest. ZMNE.

Pásztor, M. (2012). Hátrányos helyzetü 3-7 éves korú gyerekek integrált óvodai nevelése. (Letöltés: 2016.08

02.).

(Web: www.educatio.hu/bin/content/tamop311/download/tamop.../Tanulmanyok2.pdf).

Szótár (2016). Szótár plurális társadalmaknak. (Letöltés: 2016.10.09.). (Web: http.//tarstudszotar.adatbank.transindex.ro/?szo=53).

T. Molnár, G. (2011). A kultúra fogalma és értelmezései, Segédanyag (Letöltés: 2016.08.08.). (Web: $\quad$ http.//www.fk.jgytf.u-szeged.hu/tanszek/kozmuv/wp/wpcontent/segedanyag/t_molnar_gizella/segedanyag/A\%20kultura\%20fogalma $\% 20 \mathrm{es} \% 20 \mathrm{ert}$ elmezesei.doc).

Torgyik, J. \& Karlovitz, J. (2006). Multikulturális nevelés?. (Letöltés: 2016.07.29.). (Web: http.//www.docplayer.hu/1791142-Torgyik-judit-karlovitz-janos-tibor-multikulturalisneveles.html).

Torgyik, J. (2008). Multikulturális tartalmak a pedagógiában. (Letöltés: 2016.07.29.). (Web: http.//www.kih.gov.hu/documents/.../10_Multikulturalis\%20tartalmak\%20a\%20pedagogia ban.pdf).

Zygmunt, B. (1998). Modernség és ambivalencia*. (Letöltés: 2016.08.04.). (Web: http.//www.sulinet.hu/oroksegtar/data/magyarorszagi_nemzetisegek_multikulturalizmus/pa ges/004_modernseg_es_ambivalencia.htm). 